\title{
MUTUALISM AND CORAL PERSISTENCE: THE ROLE OF HERBIVORE RESISTANCE TO ALGAL CHEMICAL DEFENSE
}

\author{
John J. Stachowicz ${ }^{1}$ And Mark E. Hay ${ }^{2}$ \\ University of North Carolina at Chapel Hill, Institute of Marine Science, 3431 Arendell Street, \\ Morehead City, North Carolina 28557 USA
}

\begin{abstract}
Because seaweeds uncontrolled by herbivores can overgrow and kill corals, competition can exclude corals from temperate latitudes where herbivores generally fail to control seaweed biomass. In this study, we show that the coral Oculina arbuscula persists on reefs in temperate North Carolina where seaweeds are common by harboring the omnivorous crab Mithrax forceps, which removes seaweeds and invertebrates growing on or near the coral. In the field, corals from which crabs are experimentally removed develop a dense cover of epibionts, exhibiting reduced growth and increased mortality relative to corals with crabs, which remain epibiont-free. This crab is unusual in that it readily consumes all local seaweeds in laboratory choice assays and is not deterred by chemical defenses that suppress feeding by local fishes, sea urchins, and other crabs. This allows Mithrax to defend corals from overgrowth by chemically noxious seaweeds like Dictyota and Sargassum that are avoided by most local herbivores. However, further field manipulations under reduced light conditions demonstrate that the outcome of the crab-coral interaction is context-dependent: crabs only benefit corals in well-lit areas where seaweeds are abundant. Field observations and tethering experiments show that, by living in association with Oculina, Mithrax gains a refuge from predation. Additionally, crabs grow faster when associated with live corals than with structurally equivalent dead corals, apparently because they are able to consume lipid-rich coral mucus. This mucus provides a dietary supplement that may help corals attract and retain low-mobility symbionts such as Mithrax, securing for the coral long-term and predictable protection against competitors.

Structurally complex but competitively inferior organisms, like some corals and coralline algae, provide the biogenic habitat complexity upon which many other species depend. Because these sessile organisms may be dependent on symbionts to remove superior competitors, mutualisms can play an important, but currently underappreciated, role in structuring marine communities where biotic interactions are intense. In this study, the mutualism between Oculina and Mithrax promotes the persistence of both species in habitats from which they might otherwise be excluded by competition and predation.
\end{abstract}

Key words: associational escape; chemical defense; competition; context-dependent interactions; coral; crab; Mithrax; mutualism; Oculina; predation; seaweed; temperate reef.

\section{INTRODUCTION}

Recent experimental investigations of positive interactions such as commensalism and facilitation demonstrate that they are predictable forces capable of shaping community structure and composition (Bertness and Callaway 1994, Bertness and Leonard 1997, Callaway and Walker 1997, Holmgren et al. 1997). In habitats with extreme physical (Bertness and Hacker 1994) or biotic (Atsatt and O'Dowd 1976, Hay 1986, Littler et al. 1986, Pfister and Hay 1988, Stachowicz and Hay 1996) stresses, species resistant to these stresses modify the local environment, allowing the persistence of less tolerant species and enhancing species

Manuscript received 2 March 1998; revised 3 August 1998; accepted 11 August 1998.

${ }^{1}$ Present address: University of Connecticut, Department of Marine Sciences, 1084 Shennecossett Road, Groton, Connecticut 06340 USA. E-mail: jstach@uconnvm.uconn.edu

${ }^{2}$ Present address: School of Biology, Georgia Institute of Technology, Atlanta, Georgia 30332-0230 USA. diversity (Hacker and Gaines 1997). In contrast to this growing appreciation for the role of these one-way positive interactions in structuring ecological communities, mutualisms are still regularly portrayed as little more than natural history curiosities (but see Regal 1977, Vance 1978, Witman 1987). Thus, despite an impressive amount of amassed information about some mutualisms and their direct consequences for the participants (see reviews by Boucher et al. 1982, Addicott 1984, Boucher 1985, Bronstein 1994), there is still little rigorous empirical evidence for the broader role of $\mathrm{mu}$ tualism in ecological communities.

Tropical reef-building corals and their endosymbiotic dinoflagellates are one of the most often cited examples of the importance of mutualism to community structure and function. This association provides reef corals with the bulk of their dietary requirements (Muscatine and Porter 1977, Davies 1991), enhancing calcification rates and reef accretion. Other less-obvious, but critically important, mutualisms between cor- 
als or calcified seaweeds (coralline algae) and mobile invertebrates have been reported; in these interactions, low-mobility invertebrates gain food or shelter from the host, while enhancing host fitness by discouraging predators (Glynn 1983, 1987) or removing competitors (Steneck 1982, Coen 1988, Littler et al. 1995, Stachowicz and Hay 1996). Such studies have rarely addressed the broader implications of these associations, but where they have, these mutualisms have been shown to facilitate the production of biogenic structure (Littler et al. 1995), which can have important community and ecosystem level consequences (Lawton and Jones 1995, Jones et al. 1997).

Positive interactions between corals and herbivores are at least partially responsible for the restriction of most corals to tropical environments (Johannes et al. 1983, Miller 1998). Although temperature may play an indirect role, many temperate and subarctic habitats support corals (Cerame-Vivas and Gray 1966, Squires and Keyes 1967, Jacques et al. 1983, Schumaker and Zibrowius 1985, Ruppert and Fox 1988), and some tropical species occur where temperatures decline to $10^{\circ} \mathrm{C}$ or lower for certain months of the year (MacIntyre and Pilkey 1969, Ruppert and Fox 1988). Intolerance to cold is, therefore, not an insurmountable physical barrier. In well-lit habitats, corals are slow growing relative to seaweeds, and the persistence of coral reefs appears to be tightly linked to the high abundance of herbivores that prevent seaweed overgrowth of corals (Miller 1998). When herbivorous fishes or sea urchins are naturally or experimentally removed from tropical reefs, seaweed biomass increases dramatically and corals are smothered (Lewis 1986, Hughes 1989, 1994). In contrast, on temperate reefs, herbivorous fishes are less abundant than in the tropics and algal standing stock is typically much higher (Horn 1989, Choat 1991, Ebeling and Hixon 1991). On the temperate reefs investigated here, herbivorous fishes and urchins alter the species composition of the algal community through selective removal of preferred species, but they do not diminish total seaweed biomass (Miller and Hay 1996) and are thus unlikely to mediate coral-algal competition (see reviews in Lubchenco and Gaines 1981, Horn 1989). The dependence of corals on positive interactions with herbivores may thus help explain why corals are generally uncommon in temperate latitudes and why coral abundance is inversely correlated with algal abundance among habitats in temperate regions (Miller and Hay 1996, Miller 1998).

In contrast to this general latitudinal pattern, the coral Oculina arbuscula does co-occur with seaweeds on natural and artificial reefs in North Carolina. Although it forms much denser aggregations in poorly lit habitats where seaweeds are rare or absent, Oculina is a common member of many North Carolina reef communities (McCloskey 1970, Peckol and Searles 1984, Miller and Hay 1996). Oculina is also the only species of coral in this region with a structurally complex branching morphology that provides shelter for a species-rich epifauna. Over 300 species of invertebrates are known to live among the branches of Oculina colonies, and although only a few are obligate coral dwellers, many more are reported to complete much of their life cycle within the coral (McCloskey 1970). In this paper, we investigate the possibility that the success of Oculina on temperate reefs is derived from its ability to harbor symbiotic herbivorous crabs that mediate competition with encroaching seaweeds and invertebrates.

Using field, mesocosm, and laboratory manipulations, we demonstrate a mutually beneficial association between Oculina and the majid crab Mithrax forceps that is similar to some ant-plant mutualisms in terrestrial environments (e.g., Janzen 1966, 1969, review in Beattie 1985). The coral provides the crab with dietary supplements and shelter from predators while the crab defends the coral from overgrowth by encroaching competitors, thus enhancing coral growth and survivorship. We also experimentally examine how variation in external environmental conditions affects the outcome of this interaction, highlighting the context-dependent nature of mutualistic interactions. Our results suggest that this type of protective mutualism has population and community implications that extend beyond the participant species. The crab directly alters the local benthic community, enhancing the growth and survival of its host and ensuring the persistence of the diverse host-associated community by increasing the production of biogenic structure.

\section{Methods}

\section{Study sites and organisms}

Field experiments were performed at Radio Island Jetty near Beaufort, North Carolina, USA $\left(34^{\circ} 42^{\prime} \mathrm{N}\right.$, $\left.76^{\circ} 41^{\prime} \mathrm{W}\right)$. This rock jetty runs from just subsurface to $9 \mathrm{~m}$ depth, and field experiments were deployed at 2.0 and $6.0 \mathrm{~m}$. Although the jetty is man-made, its flora and fauna are similar to that of natural rock ledges along the North Carolina coast (Richardson 1978, Link 1980, Peckol 1982, see Results). In the summer and fall, the shallow, well-lit portion of the jetty is dominated by brown seaweeds like Sargassum, Padina, and Dictyota, whereas the deeper portions are dominated by colonial invertebrates, including the scleractinian coral Oculina arbuscula, the upright bryozoan Bugula neritina, the hydroid Eudendrium carneum, several species of tunicates, and a few sponges. Abundant omnivorous fishes include the spottail pinfish Diplodus holbrooki, the pinfish Lagodon rhomboides, and the sheepshead Archosargus probatocephalus. The predatory black sea bass Centropristis striata is also abundant. In the winter and spring, colder temperatures induce an offshore migration of most fishes and reduce activity of resident urchins (Arbacia punctulata), shifting community dominance toward more palatable red and green seaweeds and an increased abundance of 
fleshy invertebrates (Hay 1986, Hay and Sutherland 1988).

Oculina arbuscula is a branching, scleractinian coral endemic to North and South Carolina. Oculina growing in sunlit waters possess symbiotic zooxanthellae, but this relationship is facultative. In dark habitats, colonies are azooxanthellate, yet continue to grow (Miller 1995). A diverse invertebrate fauna hosted by the coral includes the majid crab Mithrax forceps (McCloskey 1970). This crab occurs from Cape Hatteras, North Carolina south through Florida and the Caribbean to Brazil on rocky shores and reefs from the intertidal to a depth of $90 \mathrm{~m}$ (Williams 1984). Mithrax has been found associated with various species of sponges and branching corals, as well as intertidally on oyster shells, and its geographic range extends well south of that of Oculina, so association with this coral is not obligate. Little is known of the ecology or feeding habits of $M$. forceps, although other crabs in the genus are herbivorous and enter into facultative associations with corals and calcified seaweeds (Coen 1988, Stachowicz and Hay 1996). To avoid biasing the results of field experiments through excessive disturbance, crabs and corals for all field, mesocosm, and laboratory experiments were collected at a depth of $9 \mathrm{~m}$ from the deck of the Liberty Ship, a large sunken ship $\sim 10 \mathrm{~km}$ from Radio Island $\left(34^{\circ} 41^{\prime} 10^{\prime \prime} \mathrm{N}, 76^{\circ} 43^{\prime} 30^{\prime \prime} \mathrm{W}\right)$.

\section{Field surveys}

We assessed which seaweeds might compete with Oculina in the field by determining the species with which it commonly co-occurs on a variety of natural and artificial hard substrate communities. Three types of sites were sampled, including an inshore rock jetty (Radio Island Jetty, $3 \mathrm{~m}$ deep), two nearshore natural rock ledges (10 km from shore, $17 \mathrm{~m}$ deep), and five offshore outcrops ( $40 \mathrm{~km}$ from shore, $27 \mathrm{~m}$ deep). The natural reefs consisted of rock ledges with a vertical relief of $\sim 3 \mathrm{~m}$. The flora and fauna at these natural reefs are generally similar to that described previously for Radio Island (see Methods: Study sites), with the exception that the offshore sites have greater proximity to the warm waters of the Gulf Stream, and thus support an increased number of tropical species. To determine patterns of abundance of sessile organisms, a $50 \times 50$ $\mathrm{cm}$ quadrat fitted with a monofilament grid of 100 random points was placed at 3-m intervals along a haphazardly located transect at each site. The plant or animal under each point was identified and recorded, as was the total number of coral colonies within each quadrat.

We determined the composition of the decapod crab community associated with Oculina by examining haphazardly selected coral heads from several North Carolina sites. We removed individual corals from two separate locations at the Liberty Ship, sealed them in plastic bags underwater, and returned them to the laboratory for examination. To broaden our survey without harvesting excessive amounts of coral, we also recorded crab abundance in corals at the two nearshore rocky outcrops mentioned previously. Using a small metal rod, we probed the recesses of each coral in a $20 \times 1 \mathrm{~m}$ belt transect at each site, counting the number and species of crabs present. Most individuals could be identified to species, but xanthid crabs were grouped together because distinctions among some of the locally occurring species in this family require microscopic examination or dissection.

\section{Field experiments}

Because Mithrax forceps was the most abundant crab living on Oculina, and other crabs of the genus consume seaweeds (Coen 1988, Stachowicz and Hay 1996), we reasoned that it might be capable of mediating competition between corals and encroaching seaweeds. To evaluate this hypothesis, we performed two field experiments monitoring fouling and growth of corals in the presence and absence of crabs. In the first manipulation, metal stakes were driven into a sandy area immediately adjacent to Radio Island Jetty at a depth of $2 \mathrm{~m}$, and one coral was fastened to each stake $0.75 \mathrm{~m}$ above the bottom. We term this the "fouling experiment" because it evaluated whether these crabs affected coral growth by reducing the load of fouling organisms recruiting to, and growing directly on, the coral. In the second experiment, corals were attached to concrete blocks placed on the jetty. We term this the "encroachment experiment" because it examined whether crabs affected coral growth by mediating interactions with encroaching benthic organisms growing on the blocks as well as those growing directly on the coral.

In the fouling experiment, performed from September 1994 to May 1995, we fastened a single coral (mean size $=229 \mathrm{~g}$ ) to each of 20 stakes, then placed a single Mithrax forceps on 10 of the corals, and left the other 10 vacant. At the end of the experiment we removed all epibionts from the coral, sorted them into gross taxonomic categories, and dried them in an oven at $65^{\circ} \mathrm{C}$ for $48 \mathrm{~h}$, before weighing to the nearest milligram. After removal of epibionts, corals were reweighed to measure growth. Because corals are modular organisms, and growth involves the production of new modules (polyps), growth can be considered a direct measure of fitness (Buss 1985). We analyzed crab-occupied and unoccupied corals for differences in epibiont load and growth rate using an unpaired $t$ test. Because some corals were lost due to storms, and some crabs disappeared from their corals during the experiment, our final sample size for analysis was six corals with crabs and eight without crabs.

In the encroachment experiment, which ran from $\mathrm{Au}-$ gust to November 1996, we transplanted 30 pairs of corals to Radio Island Jetty where they were grown on flat cement blocks $(39 \times 19 \times 4 \mathrm{~cm})$ for $102 \mathrm{~d}$. Each block with a coral was affixed to a $39 \times 19 \times 19 \mathrm{~cm}$ 
cinderblock sunk $8 \mathrm{~cm}$ into the sand between rocks of the jetty. Blocks were arranged in pairs within $1 \mathrm{~m}$ of each other, and pairs of blocks were spaced by at least $2 \mathrm{~m}$. Within a pair, a crab was added to one block but not the other. Half of the pairs were placed at $2.0 \mathrm{~m}$ depth (shallow site; $N=15$ pairs) and half were placed at $6.0 \mathrm{~m}$ (deep site; $N=15$ pairs). The blocks to which the corals were attached had been placed in the field at the shallow and deep sites for $10 \mathrm{wk}$ prior to the start of the experiment to allow a natural fouling community to develop. At least once a week throughout the course of the experiment, each coral was checked for crabs; missing crabs were replaced and new colonizers were removed to maintain treatments and controls. Mean retention of crabs was $80 \%$ between monitoring intervals (see Results). We thus avoided using cages to maintain treatments, eliminating potential artifacts associated with reduced flow, light, and abundance of large consumers.

To monitor the effect of crabs on the benthic community, we recorded the percent cover of benthic organisms on each block every 4 wk using a metal frame the size and shape of the block that was fitted with a monofilament grid of 100 points. We placed the frame over a block and recorded the seaweed or invertebrate species beneath each point; unoccupied points were recorded as bare substrate. After $102 \mathrm{~d}$ in the field, corals were collected, cleaned, and reweighed, and the benthic community growing on the blocks was harvested. Prior to removal of the community, each block was divided into three equal-sized sections: the middle third of the block immediately adjacent to the coral, and the outer third on each side. The outer thirds were pooled and contrasted with the middle third to determine if the crabs' impact on community biomass was restricted to the area adjacent to the coral. Because we were not interested in interactions among times of sampling, we analyzed percent cover data separately for each sampling date using a two-factor ANOVA with depth and crab presence as fixed factors. We adjusted $\alpha$ for these tests using the Bonferroni correction $(\alpha=$ 0.01 ) to avoid inflating our Type I error rate due to nonindependence of cover measurements across time. Coral growth was also analyzed by two-way ANOVA with fixed factors. Community biomass (dry mass per square centimeter) was analyzed separately for shallow and deep sites using ANOVA with position on the block and crab presence as fixed factors. Post hoc comparisons for each ANOVA, where appropriate, were made using Ryan's $Q$ test (Day and Quinn 1989).

\section{Whole-plant feeding assays}

To determine if Mithrax forceps readily consumed seaweeds that co-occurred with Oculina, we offered individual crabs a simultaneous choice of eight common seaweeds in laboratory experiments. Each of these seaweeds occurs in shallow waters of North Carolina in the early summer: the green alga Ulva rigida, the brown algae Padina gymnospora, Dictyota menstrualis, Dictyota ciliolata, and Sargassum filipendula, and the red algae Hypnea musciformis, Chondria dasyphylla, and Gracilaria tikvahiae. We placed each crab $(N=22)$ in a separate $0.5-\mathrm{L}$ bowl with four $1 \mathrm{~cm}$ diameter holes to allow for flow-through seawater. Each bowl with a crab held a 200-250 mg piece of all eight seaweed species. As a control for changes in seaweed mass unrelated to herbivory, 22 identical bowls without crabs contained same-sized pieces of the same species of seaweed. Within each replicate pair of bowls, treatment and control pieces of algae were taken from the same algal thallus. After $33 \mathrm{~h}$, each seaweed was blotted dry with a paper towel and reweighed.

To calculate net mass loss for each algal species due to crab feeding in the choice assays, we corrected for mass changes unrelated to herbivory using the formula, $\left[T_{\mathrm{i}} \times\left(C_{\mathrm{f}} / C_{\mathrm{i}}\right)\right]-T_{\mathrm{f}}$, where $T_{\mathrm{i}}$ and $T_{\mathrm{f}}$ are the initial and final masses of the seaweed portion in the container with a crab and $C_{\mathrm{i}}$ and $C_{\mathrm{f}}$ are the initial and final masses of the seaweed portion in the paired control. Because the amount of each species consumed may depend on other available choices (i.e., the factors are not independent; cf. Peterson and Renaud 1989), we analyzed choice data using the nonparametric Friedman's test (see Alldredge and Ratti 1986, 1992, Roa 1992). We used the same methods to assess the feeding preferences of the majid crab Libinia dubia $(N=19)$, and the xanthid crab Panopeus herbstii $(N=18)$ to see if they could also function as effective cleaners of $\mathrm{Ocu}$ lina.

As a contrast for our crab assays, we determined feeding preferences of larger omnivores that commonly co-occur with the crabs: the sea urchin Arbacia punctulata and the pinfish Lagodon rhomboides. Urchin assays were conducted in a similar manner to the crab assays, except in larger containers $(1.4 \mathrm{~L})$ with larger pieces of seaweed (700-800 mg). Ulva could not be used in the urchin assay because it was not available in sufficient quantities. We tested pinfish feeding preferences by offering a choice of seaweeds to 12 individual fish isolated in separate flow-through aquaria. A 40-L aquarium was divided in half by a piece of cloth mesh ( $0.5 \mathrm{~cm}$ diameter), and a pinfish was placed in one of the two halves. We placed 200-250 mg pieces of each of the eight seaweeds between the strands of $0.25 \mathrm{~m}$ long pieces of weighted polypropylene rope, and placed a rope in the half of each aquarium holding a pinfish. As a control for changes in algal mass unrelated to herbivory, we placed equivalent ropes, with pieces of the same species of algae, in the half of each aquarium that did not have a pinfish. Changes in mass due to herbivory were calculated and differences between species analyzed using the methods outlined for the crab assay.

\section{Assays with prey chemical extracts}

To test whether feeding preferences observed in whole-plant assays were related to plant secondary 
chemistry, we fed crabs (Mithrax and Panopeus) and urchins (Arbacia) artificial foods containing the lipophilic crude extract of each algal species using a method modified from Hay et al. (1994). Extracts of each alga were obtained by grinding a known fresh volume of each species in a blender with 2:1 dichloromethane : methanol. Solids were filtered and solvents removed by rotary evaporation. Water soluble materials in this extract were removed via ethyl acetate/water partition and discarded. We did not test the water soluble portion of the extract for deterrent effects on feeding because (1) the herbivores fed slowly, and water soluble materials would likely have leached from the artificial food before the completion of the assay, thereby compromising the results of these tests; and (2) previous assays of lipophilic and water soluble extracts from marine algae in this region have indicated that feeding is commonly affected by the lipophilic extract, but rarely by the water soluble extract (Bolser and Hay 1996).

The artificial food was made by freeze-drying the palatable alga Ulva, grinding it to a fine powder, mixing it in an agar base, and forming the mixture onto a strip of window screen. The screen provided a matrix to hold the food, as well as an internal grid that allowed us to quantify the amount eaten by counting squares from which the food had been removed (Hay et al. 1998: Fig. 2). To make the food, we mixed $2.0 \mathrm{~g}$ of dry Ulva in $5 \mathrm{~mL}$ of distilled water with $0.36 \mathrm{~g}$ of agar dissolved in $13 \mathrm{~mL}$ of boiling distilled water. This recipe yields $20 \mathrm{~mL}$ of artificial food with a water content of $90 \%$, similar to that of the seaweeds being tested (J. Stachowicz, unpublished data). Algal extracts were added to the food volumetrically by dissolving the lipophilic crude extract from $20 \mathrm{~mL}$ of seaweed in anhydrous ether, and adding this solution to the $2 \mathrm{~g}$ of dry Ulva powder in a small flask. Enough ether was added to cover the powder with liquid. The solvent was then removed by rotary evaporation, resulting in a uniform coating of the extract on the algal particles. Control foods were treated identically, but without the addition of extract to the ether. We also tested the effect of lipophilic extracts from several invertebrates (Oculina arbuscula, Eudendrium carneum, and Bugula neritina) on feeding by Mithrax by incorporating these extracts into an artificial food comprised of freeze-dried commercial fish food using the same procedure outlined for the seaweed chemical extract assays. For a detailed description of the preparation of artificial foods, see Hay et al. (1994, 1998).

The sections of window screen holding the artificial foods with and without extracts were cut into pieces measuring $10 \times 10$ squares, and offered together to individual animals in flow-through containers. Experiments were monitored regularly, and feeding was allowed to continue until either (1) over $50 \%$ of either the treatment or control food was eaten; or (2) the termination of the experiment (for replicates with low rates of feeding, usually after 12-24 h). If the herbi- vores did not feed or ate all of both foods between monitoring intervals, then that replicate was excluded from analysis because it provided no information on relative palatability of the foods. The effect of extracts on feeding was analyzed using a paired $t$ test.

\section{Predation on crabs in the field}

To determine if association with Oculina reduced predation on Mithrax, we tethered crabs at Radio Island Jetty either with or without access to a coral. Fifteen $\mathrm{cm}$ long tethers of monofilament fishing line were affixed to crab carapaces using super glue according to methods in Stachowicz and Hay (1996). The free end of the tether was tied to galvanized nail, which was driven into the substrate. Crabs with and without access to a coral were paired within $0.5 \mathrm{~m}$ of each other; separate pairs were spaced by at least $2 \mathrm{~m}$. Each tether was checked after 1 and $24 \mathrm{~h}$ to see if crabs were still present. We analyzed these data using Fisher's exact test. Although these crabs are mobile, their typical defensive response is not to flee, but rather to remain motionless and hold tightly to the substrate (J. Stachowicz, unpublished data and observations); thus we believe that tethering is an acceptable method for testing the refuge hypothesis.

As an additional test of the refuge benefits of the coral at a different site, and to ensure that our results from the previous experiment were not artifacts of the tethering process (Peterson and Black 1994), we placed untethered crabs at the Liberty Ship either with or without access to a coral, and observed them over a 2-h period. Each pair of crabs (one with and one without access to a coral placed $1 \mathrm{~m}$ apart) was observed by a scuba diver from a distance of $2 \mathrm{~m}$ for $\sim 15 \mathrm{~min}$ or until the crabs had been consumed. We recorded the length of time from placement of a crab until its consumption, as well as the species of the predator. After $15 \mathrm{~min}$, the location of surviving crabs was marked to allow them to be relocated; crabs were marked with a small drop of super glue to allow us to distinguish them from other crabs in the field. Two hours after initial placement, we rechecked any crabs that had survived the initial 15-min period. We analyzed for differences in the frequency of consumption of crabs with and without access to a coral using Fisher's exact test.

\section{Nutritional benefits to the crab}

To determine if crabs use factors other than protection from predators in selecting a habitat, we offered individual Mithrax a choice between associating with a live or a dead coral of similar size and structural complexity. Tissue was stripped from the "dead" coral using a high-pressure jet of fresh water; we then rinsed each coral in fresh water, and placed them in running seawater for $24 \mathrm{~h}$. In a 10 -L tub, we placed equal-mass heads of live and dead corals (means $\pm 1 \mathrm{SE}$, live $=$ $211.8 \pm 13.25 \mathrm{~g}$, dead $=211.1 \pm 10.14 \mathrm{~g} ; N=20, P$ $=0.967$, paired $t$ test). Thus, the two choices were 
equivalent with the exception of the presence of live coral tissue. We placed a single crab in the center of the tub, equally distant from the live and dead coral, and monitored its habitat choice after $0.25,12,18$, and $24 \mathrm{~h}$. We analyzed crab distribution on live and dead corals $(N=20)$ at each time interval using a $G$ test.

To determine if crabs might be feeding on mucus or other materials from the surface of the corals, we dyed live Oculina $(N=7)$ by holding them for $10 \mathrm{~min}$ in baths of filtered seawater containing $0.57 \mathrm{~g} / \mathrm{L}$ of neutral red. Seven control corals (unstained) were held in equivalent baths of filtered seawater without neutral red. Corals were rinsed briefly in fresh seawater to remove unbound dye and placed individually into flowthrough containers, each with a single crab. Crabs were allowed to feed on stained or unstained corals for 24 $\mathrm{h}$, and we then analyzed crab feces for the presence of the stain. Crab feces were collected from each container, weighed, and extracted with $2.5 \mathrm{~mL}$ acetone. Extracts were filtered through a plug of glass wool to remove solids, then solvents were removed using a slow stream of $\mathrm{N}_{2}$ gas. The dry extract was then dissolved in $2.5 \mathrm{~mL}$ distilled water and absorbance measured at $530 \mathrm{~nm}$ (the wavelength of maximum absorption for neutral red) in a Spectronic 21D spectrophotometer (Spectronic Instruments, Incorporated, Rochester, New York). The relative absorbance of fecal extract from crabs on stained vs. unstained corals was compared using an unpaired $t$ test. We also made direct observations of crab behavior on live corals at night with video cameras under red light, which did not interfere with their nocturnal behavior (white light caused them to hide).

To assess whether access to live corals affected crab growth, we raised individual crabs in 1500-L outdoor mesocosms for $6 \mathrm{wk}$ on both live and dead corals. Unfiltered seawater from nearby Bogue Sound entered the mesocosms through a wave generator that produced water movement conditions similar to those encountered in the field. Because these tanks were located outside and used unfiltered seawater, physical conditions in the mesocosms were similar to, and varied with, conditions in the field. Within each mesocosm, individual crabs were raised in $39 \times 19 \times 24 \mathrm{~cm}$ rectangular vexar cages $(0.5 \mathrm{~cm}$ mesh $)$ each of which contained a flat concrete slab on which was placed either a live or a dead coral ( $N=13$ for live and dead corals). Using a LICOR LI-193SA light meter attached to a LI1000 data logger (LICOR, Lincoln, Nebraska), we determined that the vexar used in making the cages screens out $50 \%$ of ambient light. We further reduced the level of incident light to $25 \%$ of surface irradiance by placing an additional sheet of vexar across the entire mesocosm. This reduced light levels inside the cages below the maximum levels that may naturally be encountered by corals and crabs under typical field conditions. Prior to the experiment, crabs were weighed (blotted wet mass), measured (carapace width), and sex

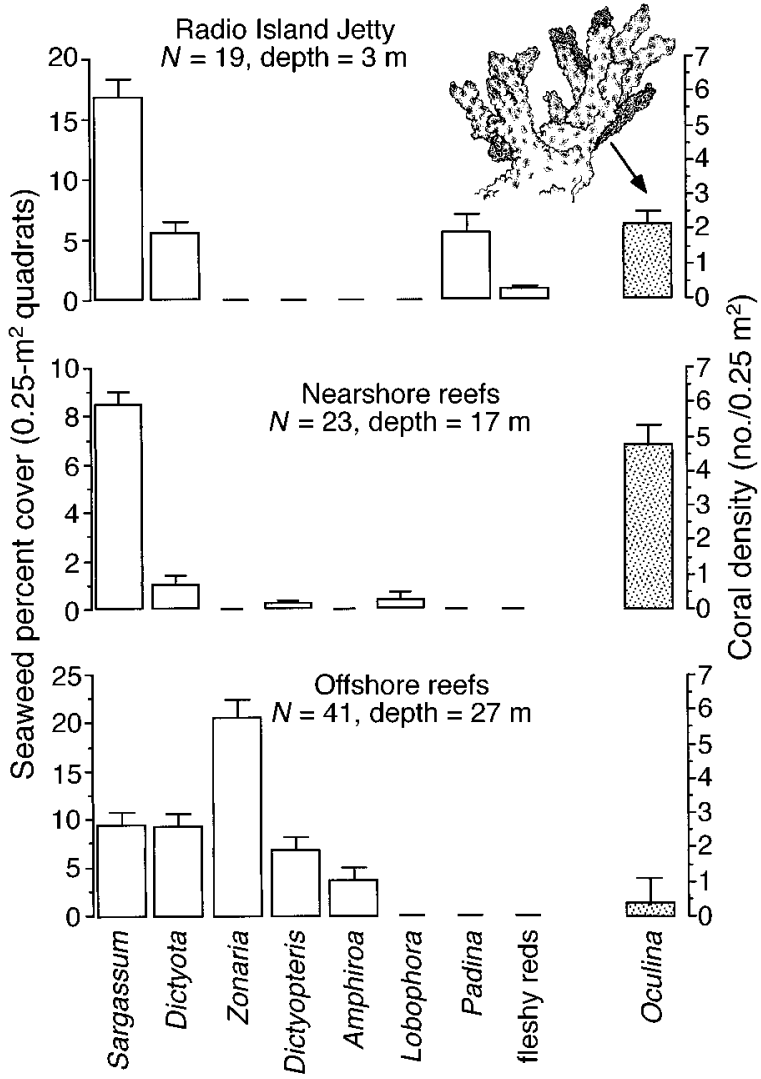

FIG. 1. Coral and seaweed abundance. Bars represent mean percent cover of seaweed or number of corals per 0.25$\mathrm{m}^{2}$ plot. Error bars represent $1 \mathrm{SE}$. Nearshore reefs are natural hardbottom sites $17 \mathrm{~m}$ deep and $10 \mathrm{~km}$ from shore; offshore reefs are $27 \mathrm{~m}$ deep and $40 \mathrm{~km}$ from shore (see Table 1).

was determined to allow us to pair the crabs on the live and dead corals within a replicate by initial size and sex. Cage sides and tops were cleaned weekly to prevent excessive fouling and sediment accumulation, but corals and cage floors were not scrubbed; rather, they were allowed to develop an epibiotic community on which the crabs could feed. Thus, crabs on dead corals were not starved, and this experiment tested whether crabs derive a greater nutritional benefit from the coral than they obtain from the natural fouling community. We compared changes in wet mass and carapace width for crabs grown on live vs. dead corals using a paired $t$ test, with separate analyses for males and females due to the large difference we found in growth rate between sexes.

\section{RESUlts}

\section{Field surveys}

Corals were common at a depth of $3 \mathrm{~m}$ on coastal rock jetties and at $17 \mathrm{~m}$ on nearshore reefs where water was turbid, but were rarer on offshore reefs at $27 \mathrm{~m}$ where water was clear (Fig. 1). Oculina was the only coral recorded in any of the quadrats. The seaweed 
TABle 1. Composition of decapod crab fauna on Oculina arbuscula in North Carolina.

\begin{tabular}{lcrccccc}
\hline \hline \multicolumn{1}{c}{ Site } & Location & $N$ & $\begin{array}{c}\text { Depth } \\
(\mathrm{m})\end{array}$ & $\begin{array}{c}\text { Mithrax } \\
\text { forceps }\end{array}$ & $\begin{array}{c}\text { Mithrax } \\
\text { pleuracanthus }\end{array}$ & $\begin{array}{c}\text { Petrolisthes } \\
\text { galathinius }\end{array}$ & Xanthidae \\
\hline Liberty Ship 1 & $34^{\circ} 41^{\prime} 10^{\prime \prime} \mathrm{N}, 76^{\circ} 43^{\prime} 29^{\prime \prime} \mathrm{W}$ & 24 & 9 & $1.42(0.195)$ & $0(0)$ & $1.25(0.367)$ & $0.333(0.177)$ \\
Liberty Ship 2 & $34^{\circ} 41^{\prime} 10^{\prime \prime} \mathrm{N}, 76^{\circ} 43^{\prime} 30^{\prime \prime} \mathrm{W}$ & 50 & 9 & $0.760(0.110)$ & $0.061(0.031)$ & $0.500(0.115)$ & $0.260(0.080)$ \\
Inshore Reef 1 & $34^{\circ} 06^{\prime} 05^{\prime \prime} \mathrm{N}, 77^{\circ} 45^{\prime} 02^{\prime \prime} \mathrm{W}$ & 58 & 17 & $0.400(0.088)$ & $0.086(0.037)$ & $0(0)$ & $0(0)$ \\
Inshore Reef 2 & $34^{\circ} 05^{\prime} 29^{\prime \prime} \mathrm{N}, 77^{\circ} 40^{\prime} 30^{\prime \prime} \mathrm{W}$ & 81 & 17 & $0.321(0.058)$ & $0(0)$ & $0(0)$ & $0(0)$ \\
Offshore Reef & $34^{\circ} 01^{\prime} 06^{\prime \prime} \mathrm{N}, 77^{\circ} 36^{\prime} 00^{\prime \prime} \mathrm{W}$ & 8 & 27 & $0.500(0.189)$ & $0(0)$ & $0(0)$ & $0(0)$ \\
\hline
\end{tabular}

Note: Values are mean number of crabs per coral; standard errors are given in parentheses.
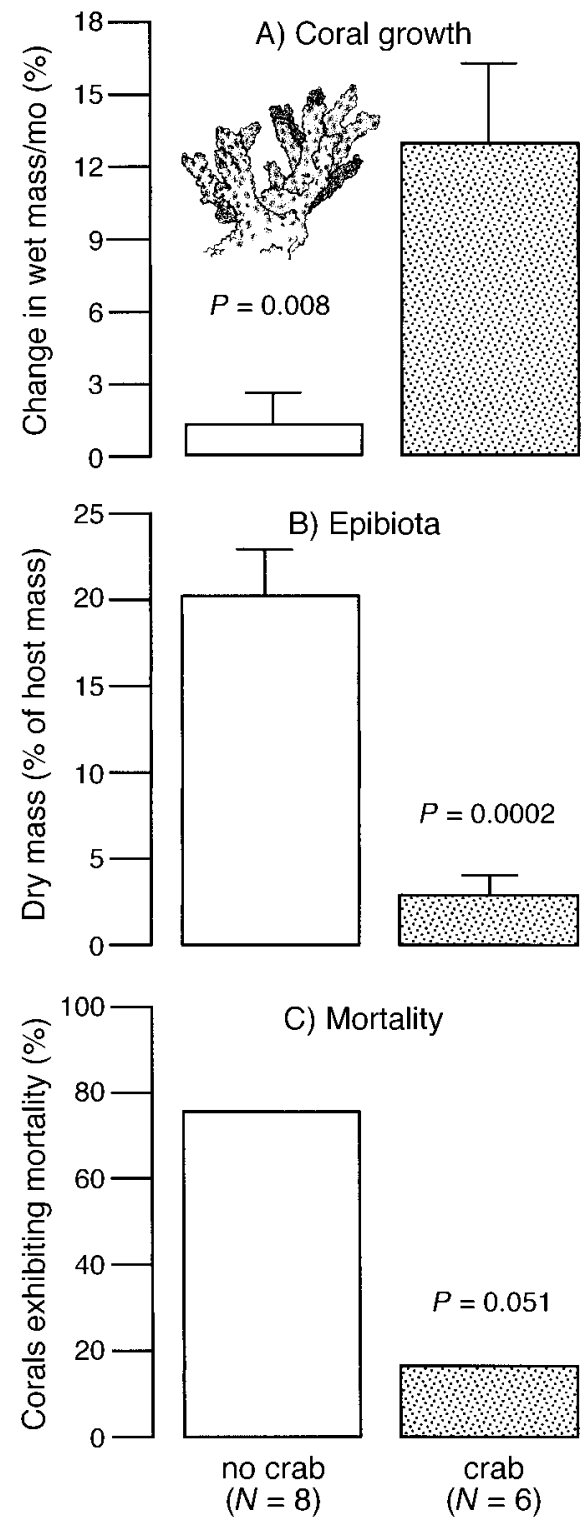

FIG. 2. Fouling experiment (September-May): (A) growth (\% change in wet mass/mo); (B) fouling (dry mass of epibionts as a percentage of host wet mass); and (C) mortality of corals with and without Mithrax forceps. In panels (A) and (B), values are means, error bars represent $1 \mathrm{SE}$, and statistical analysis is by unpaired $t$ test. In panel (C), analysis is by Fisher's exact test. community at all sites was dominated by brown algae. At sites where corals were most abundant, Sargassum was the dominant seaweed, with Dictyota and Padina also being common (Fig. 1). Surveys of the abundance of crabs in Oculina heads from three offshore sites in North Carolina indicated that Mithrax forceps was the most common crab on these corals (Table 1). This crab occurred at densities between 0.32 and 1.42 crabs per coral. The other majid found in our surveys (Mithrax pleuracanthus) was far less common, occurring at a maximum density of one crab per 10 corals at the $10-\mathrm{km}$ reef. Neither the lone porcellanid species found in our samples (Petrolisthes galathinius) nor the xanthids occurred as commonly as Mithrax forceps. Additionally, although the xanthid and porcellanid crabs were common at the two locations on the Liberty Ship, they occupied no corals on the three natural reefs that we sampled (Table 1).

\section{Field manipulations}

In the fouling experiment, corals occupied by Mithrax forceps grew 10 times faster than unoccupied colonies $(P=0.008$, Fig. 2A) and accumulated only oneseventh of the fouling organisms $(P=0.0002$, Fig. 2B). Seaweeds (primarily Codium and Ectocarpus) formed a small component of the overgrowth on corals without crabs during this fall-spring experiment; most overgrowth was due to invertebrates, particularly colonial and solitary ascidians (Botryllus, Styela), sea anemones (Aiptasia), and barnacles (Balanus spp.). Corals without crabs did not show a change in mass (i.e., growth) that was significantly different from zero ( $P=0.409$, one sample $t$ test). Given the large difference in the abundance of fouling organisms on corals with and without crabs, we expected greater coral mortality among colonies without crabs, so we used a onetailed Fisher's exact test to evaluate this hypothesis. Corals without crabs did exhibit greater mortality (Fig. $2 \mathrm{C}, P=0.051)$, as three of the eight coral colonies without a crab experienced total mortality and three sustained partial mortality (i.e., areas of the coral where living polyps had been killed), whereas only one of the six corals with crabs exhibited even partial mortality.

In shallow, well-lit habitats where algae dominate, Mithrax was especially important in defending corals from algal overgrowth (Figs. 3-5). In the encroachment experiment, Mithrax enhanced coral growth and de- 


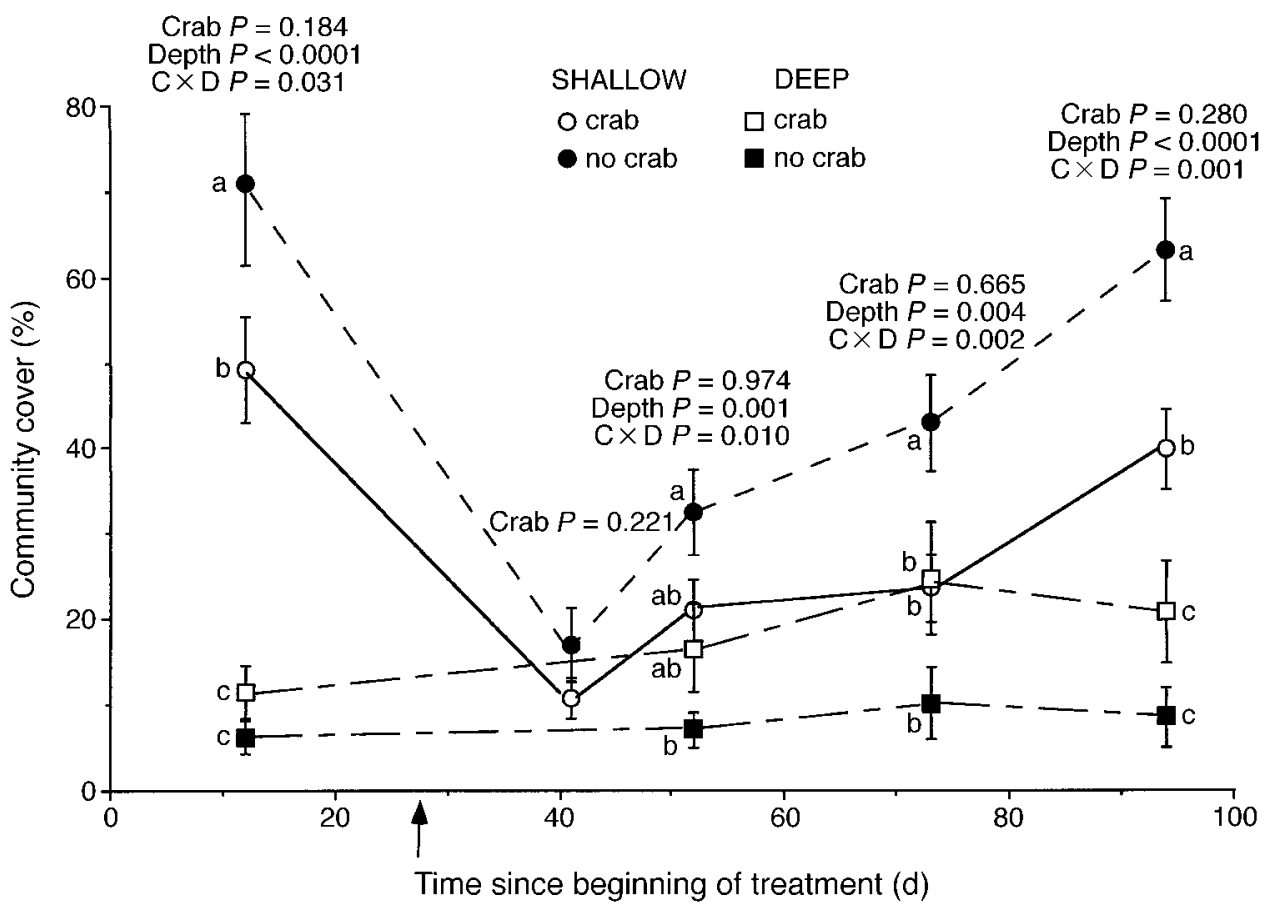

FIG. 3. Total percent cover (mean $\pm 1 \mathrm{SE}$ ) of all organisms on blocks from the encroachment experiment (AugustNovember, 1996). Results of separate ANOVAs for each date are given on the figure. $N$ for the first sampling date was 15; $N$ for all remaining dates was 14 . Letters indicate significant $(P<0.05)$ among-treatment differences in cover at that time period. The arrow beneath the $x$-axis indicates the occurrence of Hurricane Fran.

creased the biomass and cover of the benthic community surrounding corals on the shallow, but not the deeper blocks. After just 20 d, crabs had depressed total cover of organisms (community cover), relative to controls, on the shallow blocks, while there was never a difference between corals with and without crabs on the deep blocks ( $\alpha=0.05$, Fig. 3). This was not a function of differential retention of crabs because site fidelity did not differ between the shallow and deep location, as $79.4 \pm 3.7$ and $76.2 \pm 5.2 \%$ of crabs placed on corals were still present each time corals were checked at the shallow and deep sites, respectively (7-10 d intervals, $N=11$ different determinations during this experiment; $P=0.609$, paired $t$ test). At every sampling period where data could be taken at both depths, there was an interaction between depth and treatment, reflecting the fact that crabs depressed total cover in shallow water $(P<0.05)$ and slightly enhanced it in deeper water (nonsignificant trend, $P>$ 0.05, Fig. 3). The large decrease in percent cover on the shallow blocks both with and without crabs around day 30 was associated with Hurricane Fran. Rough seas during this period removed much of the benthic community from the substrate both on the blocks and on the surrounding reef, and destroyed one replicate at each depth. Additionally, immediately following the storm the water remained turbid for several weeks, probably slowing algal growth and interrupting the crab treatment effect for $\sim 1$ mo. By early October (day 53) there was a nonsignificant trend toward a decrease in community cover on blocks with crabs at the shallow site, and by late October (day 76) this effect was statistically significant (see Fig. 3). Because of the hurricane-generated disturbance, our data may underestimate the normal cumulative impact of these crabs at the shallow site.

Crabs appeared to be indiscriminate removers of fouling organisms; although they significantly reduced the total cover of benthic organisms, they had no effect on species composition. There were no significant differences in the relative cover (percentage of total cover) of any species between crab and no-crab treatments for a given date and sampling depth (paired $t$ tests, $P>$ 0.05 , Fig. 4). Shallow blocks were consistently dominated by the brown seaweeds Dictyota menstrualis and Sargassum filipendula, with occasional red algae in the understory (Hypnea and Chondria). During one sampling period, the red alga Spyridia hypnoides was found loosely snagged onto several corals, apparently via detachment and drift of adult algal fronds. A shift from a Dictyota-dominated to a Sargassum-dominated community occurred between day 10 and 40 (Fig. 4), associated with both decreasing water temperatures and the occurrence of the hurricane. The arborescent bryozoan Bugula neritina also increased in abundance later in the season. Seaweeds rarely grew at the deep site, where the blocks were consistently dominated by a low 

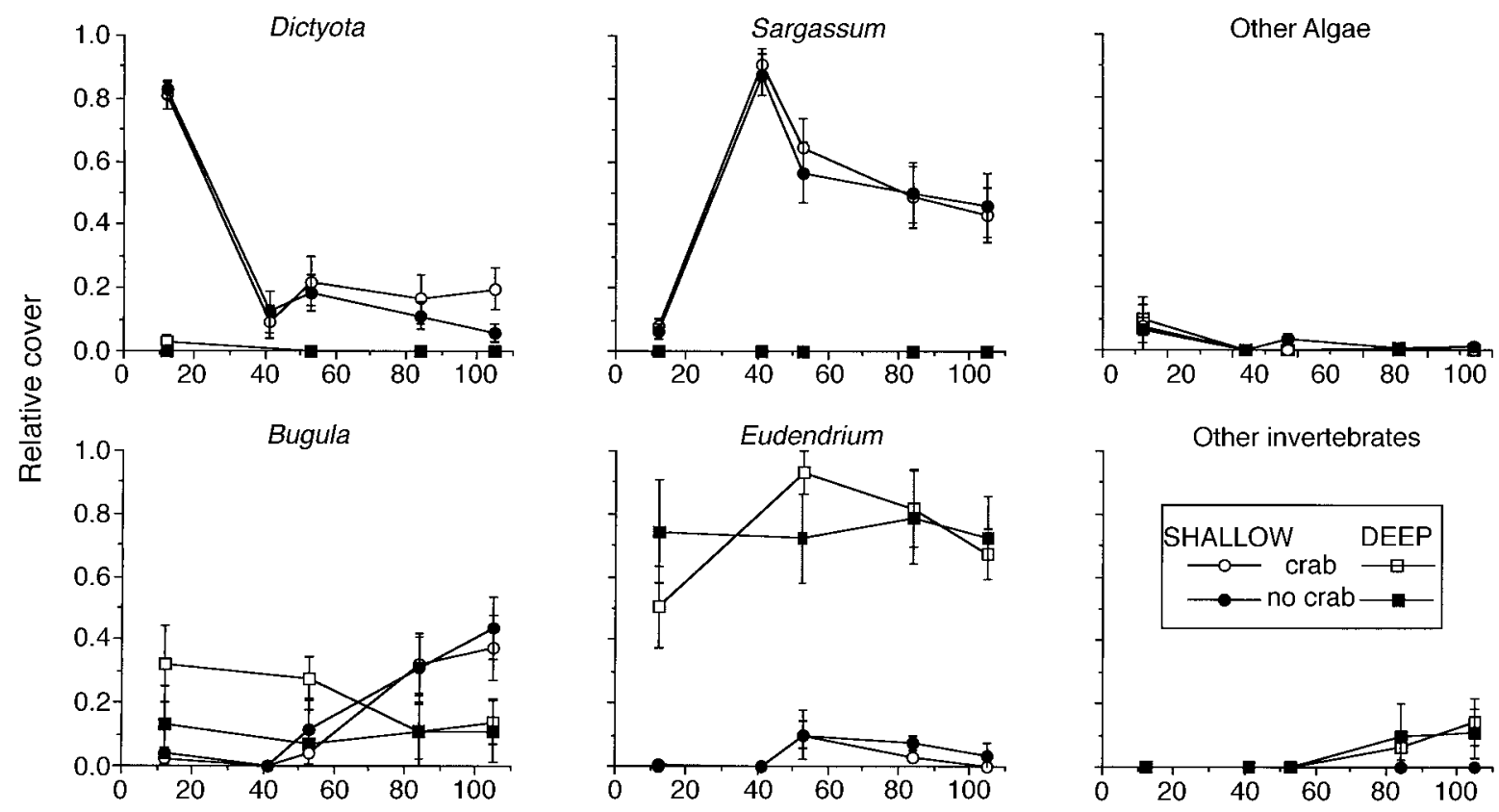

FIG. 4. Relative cover (mean $\pm 1 \mathrm{SE}$ ) of dominant species or groups on blocks in the encroachment experiment. Paired $t$ tests between blocks with and without crabs at each depth for each date indicated no significant effects of crabs on relative cover of seaweeds or invertebrates. Sample sizes are as in Fig. 3.

absolute cover of Bugula and the hydroid Eudendrium carneum.

At the shallow site, crab impact on community cover was localized to areas immediately around the coral. Crabs reduced total community dry mass and there was reduced dry mass in the middle of the blocks compared to the outer portions $(P=0.013$ and 0.005 , respectively), but there was no significant interaction between these factors $(P=0.190$, Fig. 5A). Although we may have had insufficient power to detect a significant interaction between crab presence and location on the block in the full ANOVA, total community dry mass on blocks with crabs was three times greater on the outer portions of the blocks than in the middle (Fig. 5A, Ryan's $Q$ test, $P<0.05$ ), whereas community biomass did not differ between the middle and the outer portions of blocks without crabs. On the deep blocks, neither crab presence nor location on the block affected community biomass, and there was no interaction between these factors $(P=0.372,0.132$, and 0.406 , respectively; two-way ANOVA, Fig. 5B). Apparently, in shallow waters dominated by seaweeds the feeding activities of these crabs result in a halo of decreased biomass immediately surrounding their host; this effect is not apparent in deeper waters where seaweeds are rare and benthic invertebrates more common (Figs. 4 and 5). Correspondingly, in shallow water corals with crabs grew $65 \%$ more than corals without crabs, while there was no detectable effect of crabs on coral growth at the deep site (two-way ANOVA: crab $P=0.023$, depth $P=0.001$, interaction $P=0.232$; see Fig. $5 \mathrm{C}$ for post hoc tests at $\alpha=0.05$ ). Thus crabs significantly benefited corals only at shallow depths where seaweeds occur (Fig. 4) and total cover is high (Fig. 3).

\section{Feeding preference assays}

In assays with whole seaweeds, Mithrax was a less discriminating feeder than the pinfish Lagodon rhomboides, the urchin Arbacia punctulata, or the crabs Panopeus herbstii and Libinia dubia (Fig. 6). Mithrax preferred Dictyota menstrualis over most other species, but this crab consumed large amounts of all species with minimal distinction among species (Fig. 6C). In contrast, the fish, urchin, and other crabs strongly avoided brown seaweeds, and consumed primarily red and green seaweeds such as Ulva, Hypnea, Gracilaria, and Chondria. Pinfish preferred Hypnea, but also consumed significant amounts of Ulva and Chondria (Fig. 6A). Urchins consumed Gracilaria, Hypnea, and Chondria in large amounts (Fig. 6D). Other than Mithrax, only Libinia dubia consumed significant quantities of any brown seaweeds, eating Padina at levels not significantly different from Chondria (Fig. 6B). However, both Libinia and Panopeus strongly avoided consuming Sargassum and both species of Dictyota (Fig. 6B and E). Thus Mithrax was the only species that readily consumed the wide variety of brown seaweeds that commonly co-occur with Oculina (Fig. 1).

The proximate mechanism for the broad diet of Mithrax appears to be its resistance to chemical deterrents 

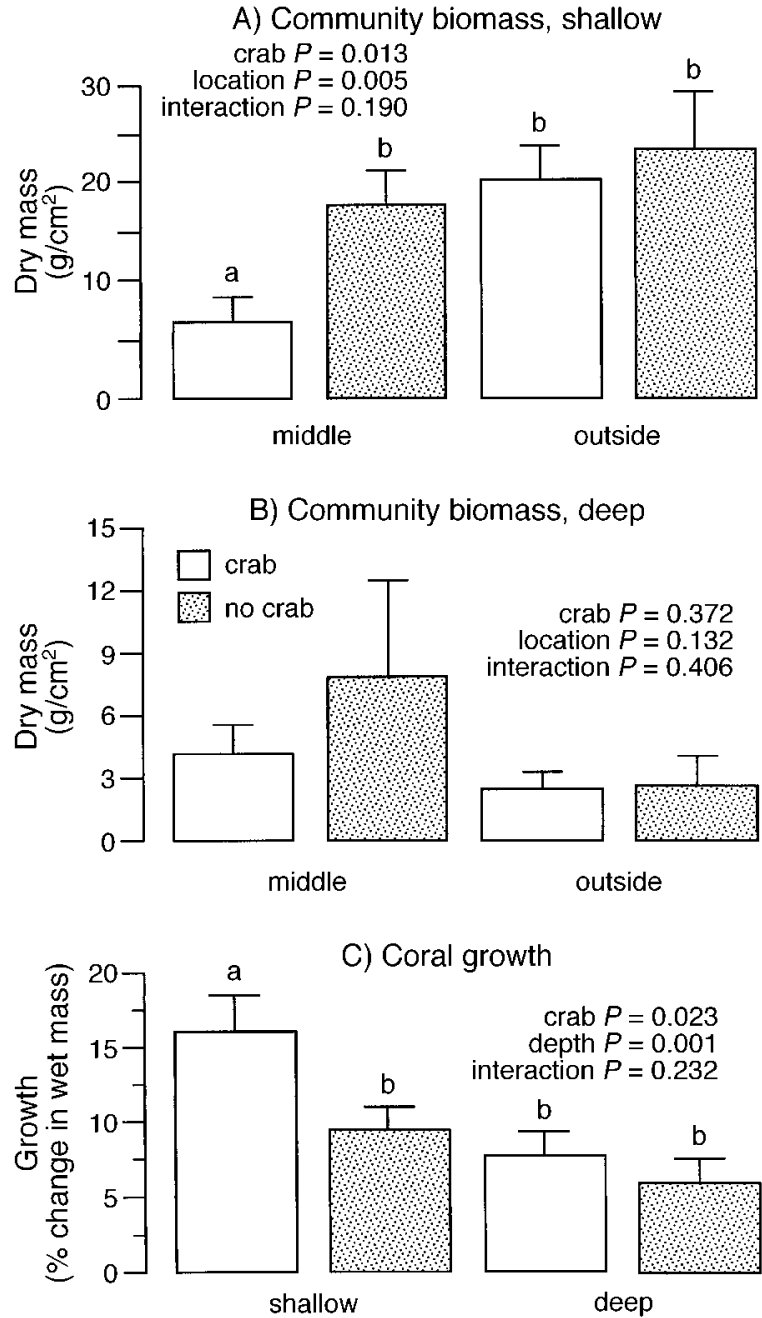

FIG. 5. Effects of Mithrax forceps on community biomass and coral growth at the end of the encroachment experiment. Community biomass is given as dry mass per $\mathrm{cm}^{2}$ (mean + $1 \mathrm{SE}$ ) for (A) shallow and (B) deep sites. Analyses were by two-factor ANOVA with position on block (middle vs. outer portion) and crab presence as fixed factors with $N=14$ for each treatment combination. (C) coral growth is expressed as the total percentage change in wet mass over the course of the experiment (mean $+1 \mathrm{SE}$ ). Analysis was by two-factor ANOVA with depth and crab presence as fixed factors and $N=14$. Different lowercase letters above histogram bars within a panel indicate significant differences $(P<0.05)$.

produced by these seaweeds. None of the extracts tested significantly deterred feeding by Mithrax $(P>0.05)$, and the extract of Padina actually stimulated feeding (Fig. 7A, paired $t$ test, $P=0.0003$ ). In contrast, Panopeus was significantly deterred by extracts from both Dictyota species (Fig. 7B), and there was a nonsignificant trend $(P=0.080)$ for deterrence in the extract of Padina. Similarly, four of the six extracts tested ( $D$. menstrualis, D. ciliolata, Sargassum, and Hypnea) significantly deterred feeding by sea urchins $(P<0.05$, paired $t$ test, Fig. 7C). Thus, several of the dominant species on the blocks with corals and on nearshore reefs (Dictyota, Sargassum) are chemically defended from grazers other than Mithrax.

\section{Benefits to the crab from associating with Oculina}

Crabs tethered directly to the jetty at Radio Island were more likely to be consumed than crabs tethered near corals both after 1 and $24 \mathrm{~h}$ (Fig. $8, P=0.0001$ and 0.008 , respectively), indicating that the association reduces predation on the crab. Similarly, in our tetherless experiment at the Liberty Ship, crabs without access to a coral were more likely to be consumed than those with access to a coral after both $15 \mathrm{~min}$ and $2 \mathrm{~h}$ (Fig. 8, $P<0.0001$ ). Our observations of these nontethered crabs indicated that they often survived for several minutes in the open by remaining motionless, but as soon as they moved, they were attacked and rapidly consumed. The mean survival time of the 11 untethered crabs placed outside corals that were eventually consumed was 3 min $7 \mathrm{~s}$ (3:07). Two crabs without access to a coral were not observed to be consumed by fishes; one reached the shelter of a coral in 1:01, and the other was not consumed after being in the open for 16:41, but was missing when we checked the point of its release after $2 \mathrm{~h}$. All of the crabs placed on a coral remained intact after $2 \mathrm{~h}$. The black sea bass (Centropristis striata) was the primary consumer of untethered crabs at the Liberty Ship (10 of 11 acts of predation observed); spottail pinfish (Diplodus holbrooki) were also frequently observed attacking crabs, and on one occasion consuming them.

When given a choice between live and dead Oculina heads, crabs initially did not discriminate between the two $(P=0.527)$, but gradually moved to live corals such that after 12,18 , and $24 \mathrm{~h}$, more of the crabs occupied live corals than dead corals (Fig. 9, $P \leq$ 0.001). In mesocosm experiments, crabs grew faster on live corals than on dead corals, but this effect was sex dependent. When measured as change in carapace width or as change in wet mass, female Mithrax grew faster on live than on dead corals (Fig. 10, paired $t$ tests $P=0.010$ and $P=0.029$ ), while males grew equally well on live and dead corals $(P=0.421$ and $P=0.818$ ).

This increased growth rate among crabs on live corals may be due to supplemental nutrition obtained by consuming coral mucus. Both male and female crabs observed at night under red light repeatedly scraped and plucked at the surface of the coral with their chelae, then brought the chelae to their mouth and moved their maxillipeds as they do while feeding, yet we observed no obvious damage to the corals as a result of these activities. Crabs of both sexes placed on corals stained with neutral red produced dark red feces within $24 \mathrm{~h}$. The relative absorbance of extract from these feces at $530 \mathrm{~nm}$ was $0.625 \pm 0.129$ while that from feces of crabs on unstained corals was $0.046 \pm 0.008$ (means $\pm 1 \mathrm{SE} ; N=7 ; P=0.001$, unpaired $t$ test). There was 

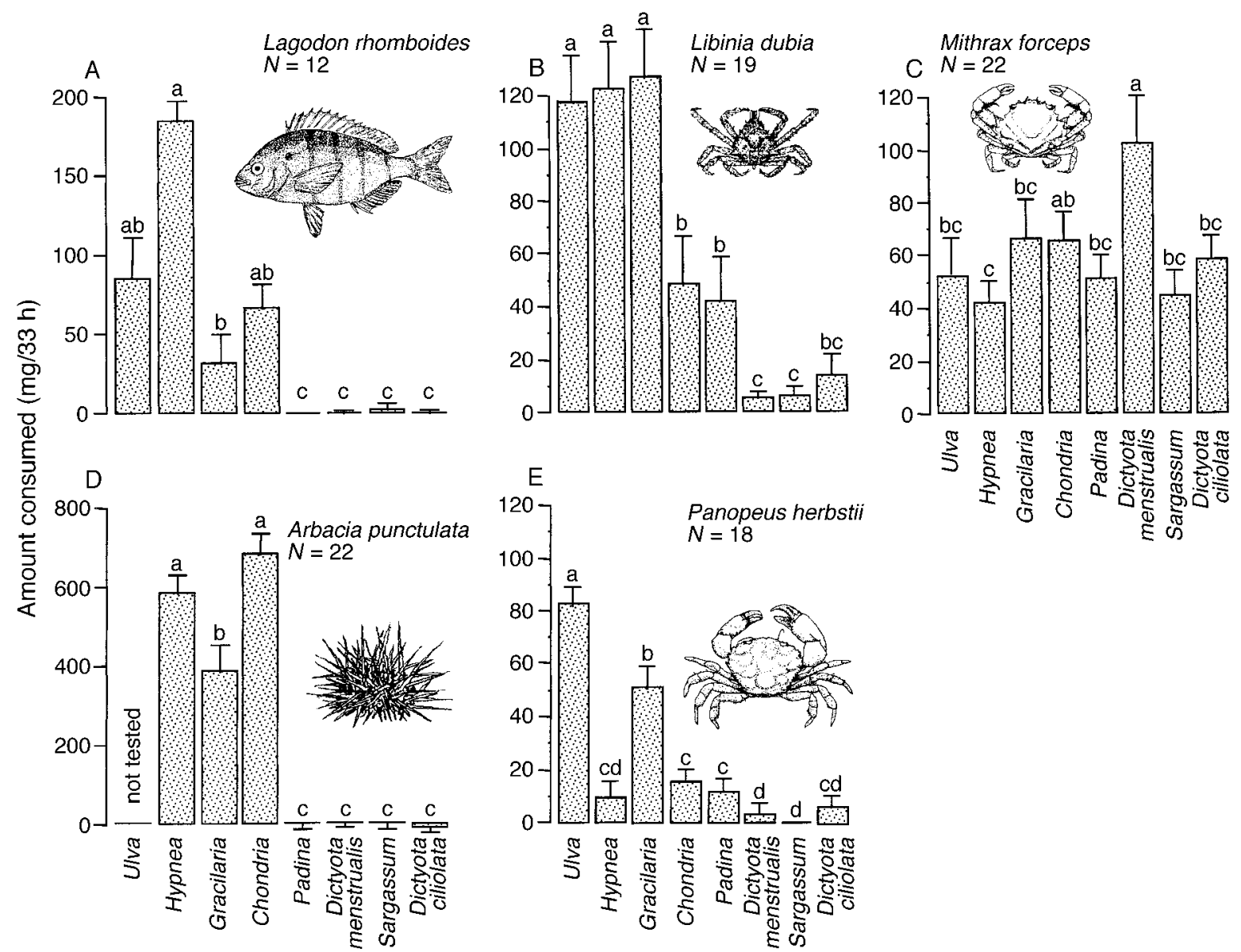

FIG. 6. Multi-choice feeding assays. Amount consumed over the duration of the assay (mean $+1 \mathrm{SE})$ for (A) the pinfish Lagodon rhomboides; (B) the spider crab Libinia dubia; (C) Mithrax forceps; (D) the sea urchin Arbacia punctulata; and (E) the mud crab Panopeus herbstii. Analyses were by Friedman's test. Within each panel, histogram bars that do not share a lowercase letter indicate significant differences between means $(P<0.05)$.

no difference in the dry mass of feces produced by crabs on stained and unstained corals $(P=0.774$, unpaired $t$ test) so differences in absorbance were not caused by increased feeding on stained corals. Recognition of Oculina and initiation of scraping behavior may be chemically cued, as lipophilic crude extracts from Oculina stimulated feeding by Mithrax $(P=$ 0.030 , Fig. 11). This stimulation was not simply a consequence of the additional nutrition found in the lipophilic extracts of all animals because extracts from Eudendrium carneum and Bugula neritina deterred, rather than stimulated, crab feeding (Fig. 11; $P=$ 0.002 , and $P<0.0001$, respectively).

\section{Discussion}

The mutualistic interaction between Mithrax forceps and Oculina arbuscula may have significant consequences for the population biology of the species involved and for benthic community structure in general. These crabs protect their host from competition by removing fouling epibiota (Fig. 2B) and clearing en- croaching seaweeds (Figs. 3 and 5A). Seaweeds or invertebrates compete with corals by shading or direct overgrowth (Jacques et al. 1983, Miller 1995), by allelopathy (de Nys et al. 1991), and/or by physically abrading the coral (Coyer et al. 1993). Thus their removal by crabs results in increased coral growth and survivorship (Figs. 2A, C, and 5C). Because Oculina derives the bulk of its nutrition from photosynthetic symbionts (Miller 1995), shading may have a greater impact than reduced heterotrophy, although there is evidence for both exploitative and interference competition between Oculina and seaweeds (Miller and Hay 1996).

In well-lit habitats, corals are slow-growing relative to fleshy macroalgae and are thus susceptible to being overgrown where herbivory is insufficient to reduce the abundance of seaweeds (Lewis 1986, Hughes 1989, 1994). On North Carolina reefs, grazing by fishes and urchins can alter seaweed species composition, but does not reduce total biomass, so these herbivores are ineffective at facilitating coral growth (Miller and Hay 

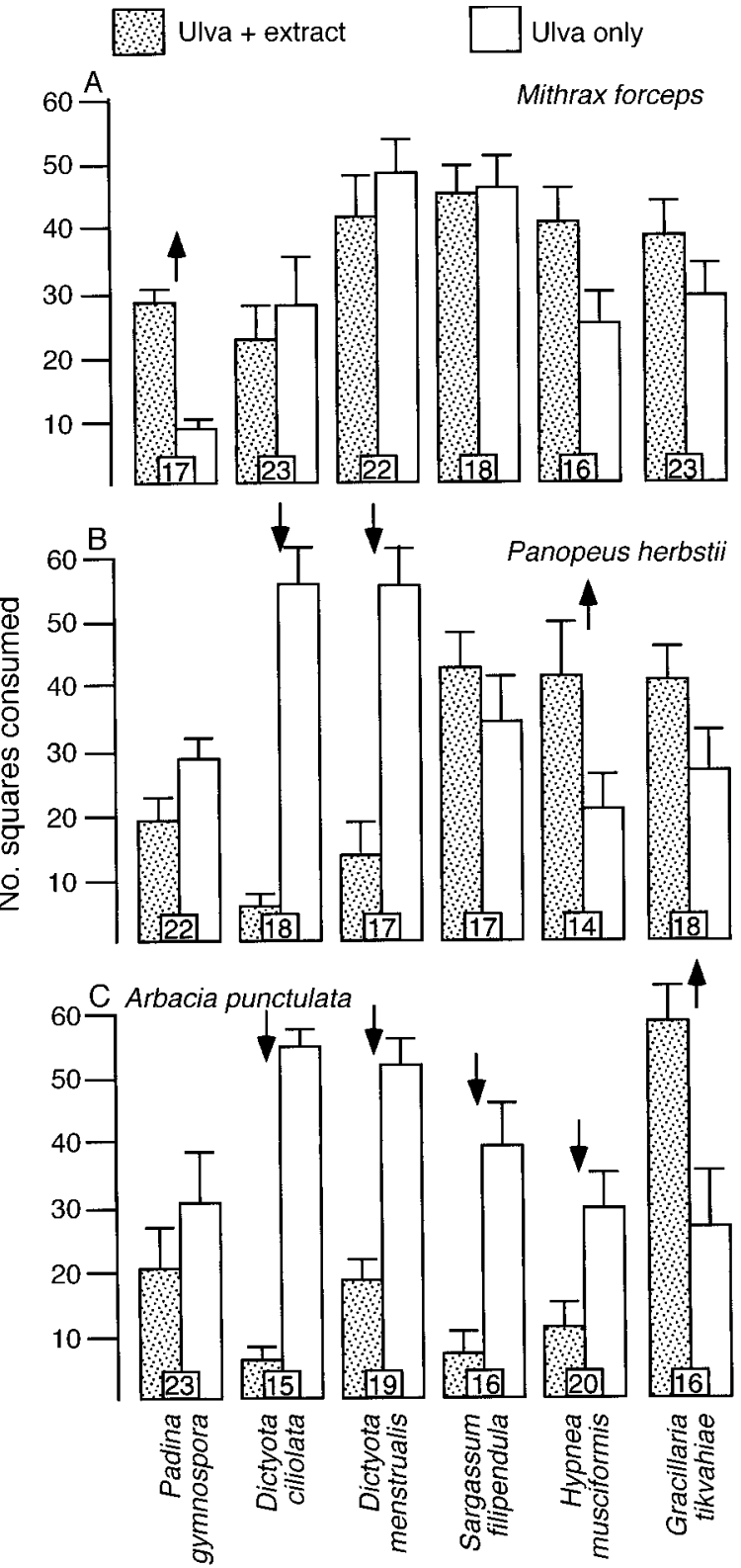

FIG. 7. Effects of seaweed chemical extracts on feeding by (A) Mithrax forceps; (B) Panopeus herbstii; and (C) Arbacia punctulata. Analyses were by paired $t$ test, and $N$ is given at the base of each pair of bars. Arrows pointing up indicate that an extract significantly stimulated feeding, and arrows pointing down indicate that an extract significantly deterred feeding $(P<0.05)$.

1996). In contrast, Mithrax reduces local community biomass (Fig. 5A), but causes no change in species composition (Fig. 4). This is likely because Mithrax exhibits little selectivity in food choice, consuming a wide variety of seaweeds including those avoided by, and chemically defended from, other herbivores (Figs. 6 and 7; also see Hay et al. 1987, 1988, Cronin and Hay 1996). These brown algae, particularly Sargassum and Dictyota species, are the most common plants cooccurring with Oculina on both natural and artificial reefs (Fig. 1), and are thus critical targets for removal by potential mutualists. We could not directly test whether local crabs other than Mithrax forceps could prevent overgrowth of corals in the field because individuals of these species would not remain on corals for longer than one day. However, because only Mithrax readily consumes the chemically noxious seaweeds that co-occur with Oculina, it alone appears capable of adequately mediating competition between Oculina and seaweeds in the field.

Refuge from predation rather than nutrition appears to be the most important selective factor driving crabs into this association. Although there may be potential problems with tethering experiments (cf. Peterson and Black 1994), experiments with and without tethers in two different sites bracketing the range of coral and crab densities in the field both support the conclusion that crabs gain a refuge from predation by associating with Oculina. Although crabs derive additional nutritional benefits from associating with live Oculina, only gradually over a $12-24 \mathrm{~h}$ period did individual Mithrax express a preference for live corals, suggesting that this choice was made only once predation risk was determined to be low. That a refuge from predation may drive habitat selection by Mithrax would not be surprising, given that predation pressure on small herbivores is often intense. Predation refuges may commonly drive the formation of associations with chemically or morphologically defended plants or animals (see reviews in Hay 1992, 1997). We suggest that escape from predation may have driven the initiation of this association as a fairly loose interaction, while the more specialized trophic component (Fig. 10) and chemically mediated stimulation of feeding (Fig. 11) may have arisen later. The production of dietary supplements may help attract and retain facultative symbionts such as Mithrax, securing long-term protection against encroaching competitors for the coral.

The increased growth of female crabs on live corals is likely derived from ingesting coral mucus, which is commonly rich in lipids and other high-energy organic compounds (Coles and Strathmann 1973, Benson and Muscatine 1974, Ducklow and Mitchell 1979). Many coral-associated crustaceans, including several from Oculina arbuscula, are known to use coral mucus as a food source (Knudsen 1967, McCloskey 1970, Castro 1976). The coral Pocillopora damicornis produces fat bodies held within its polyps that are consumed by mutualistic crabs in the genus Trapezia (Stimson 1990). Although we did not look for them in Oculina, lipid droplets occur in the mucus of many corals and may be bound in vesicles (Crossland et al. 1980) allowing for easy harvest and use by mutualists. The frequently observed plucking behavior of Mithrax on live Oculina suggests that this coral may produce similar rewards to attract and retain mutualists, just as numerous ter- 
FIG. 8. Predation on Mithrax forceps with vs. without access to a coral. The assay at Radio Island Jetty used crabs on monofilament tethers, tethered crabs observed directly by divers. Analysis was by Fisher's exact test. $N$ is given at the base of each pair of bars. whereas the assay at the Liberty Ship used un-

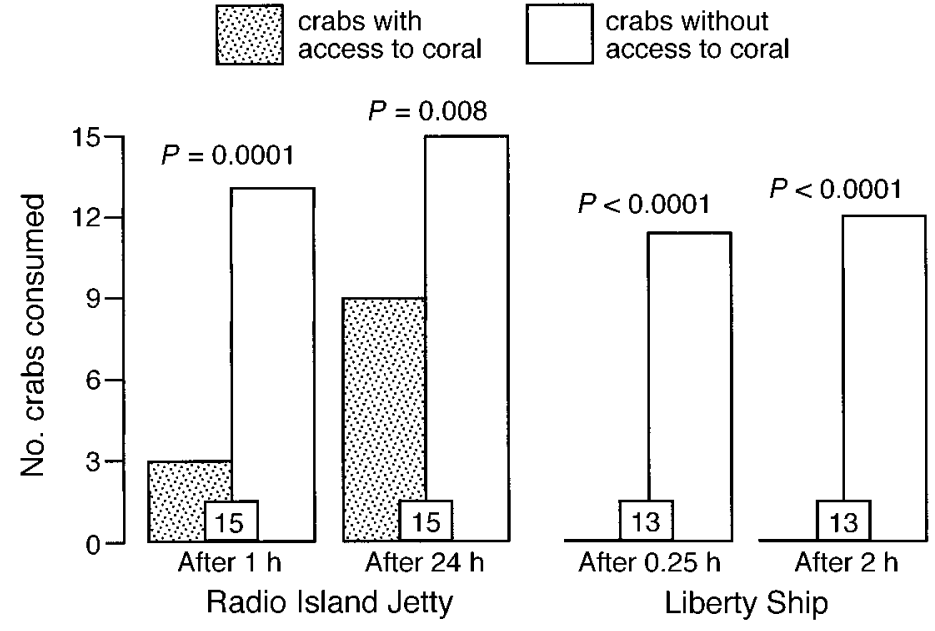

restrial plants produce food rewards for their ant mutualists (e.g., Janzen 1966, reviewed by Beattie 1985). The potential caloric value of coral mucus and fat bodies relative to seaweeds suggests that these could provide good dietary supplements to herbivores like Mith$\operatorname{rax}$.

We could find no previous reports of differential use of coral products by male and female symbionts, and it is unclear why male Mithrax did not benefit from mucus consumption in our experiments. Although the small number of male crabs used in the crab growth experiment reduced our power to detect potential differences in growth between males from live and dead corals, there does not appear to be any trend in the data that might become more apparent with increased replication (Fig. 10). One possible explanation for the male-female difference is that male crustaceans are generally more mobile than females, which tend to spend more time sheltering and less time foraging than

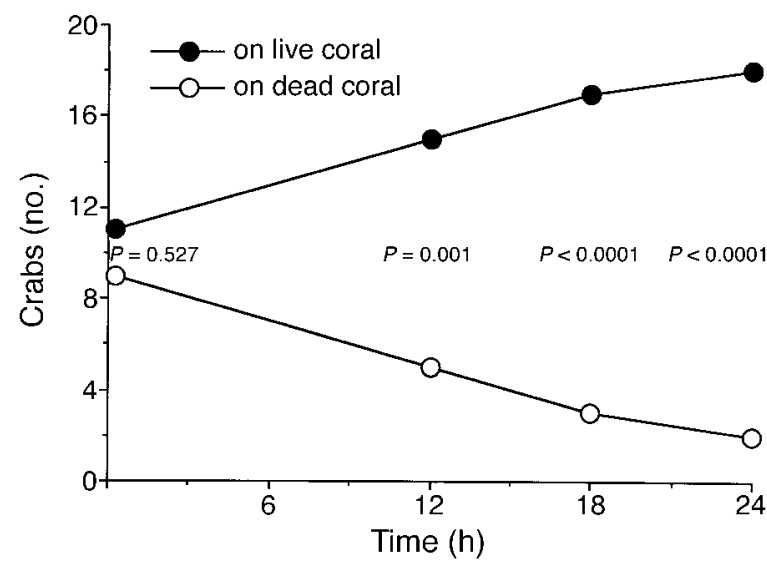

FIG. 9. Habitat choice between live and dead Oculina arbuscula by Mithrax forceps over a 24-h period. Statistical analyses of the proportion on live vs. dead corals at each time period were performed using a $G$ test $(N=20$ for each test). males (Jormalainen and Toumi 1989, Merilaita and Jormalainen 1997). Thus there may be increased selection for female Mithrax to take advantage of host-associated nutritional supplements.

\section{Community consequences of protective mutualisms}

On temperate reefs, where grazing rates are low and seaweed biomass is high (Gaines and Lubchenco 1982, Hatcher and Rimmer 1985, Horn 1989, Ebeling and Hixon 1991), most corals are restricted to habitats where seaweeds cannot grow (Miller 1998). Although 12 species of corals are known to occur in coastal North Carolina and the adjacent waters on the continental shelf, most are restricted to deep or turbid water (Cerame-Vivas and Gray 1966, MacIntyre and Pilkey 1969, Ruppert and Fox 1988), and only Oculina arbuscula commonly co-occurs with seaweeds on natural hardbottom reefs (McCloskey 1970, Peckol and Searles 1984; Fig. 1). Oculina is also the only one of these species with a branching morphology capable of protecting herbivorous symbionts like Mithrax; the other species are small tube corals (Cladocora coespidosa), encrusting or mounding corals (Siderastrea radians, Siderastrea siderea, Astrangia danae, Solenastrea hyades), or solitary cup corals (Bathycyathus maculatus, Dasmosmilia lymani, Monomyces fragilis, Paracyathus defilipii). The branching morphology of Oculina and its ability to shelter herbivorous crabs like Mithrax may account for its persistence and success in seaweeddominated temperate areas.

Structurally complex organisms like branching corals and coralline algae may commonly harbor protective symbionts that appear to suppress competitors and extend host ranges into more biologically stressful environments (see e.g., Glynn 1987, Coen 1988, Littler et al. 1995, Stachowicz and Hay 1996). Additionally, several other studies have demonstrated communitylevel effects of mutualisms involving structurally com- 

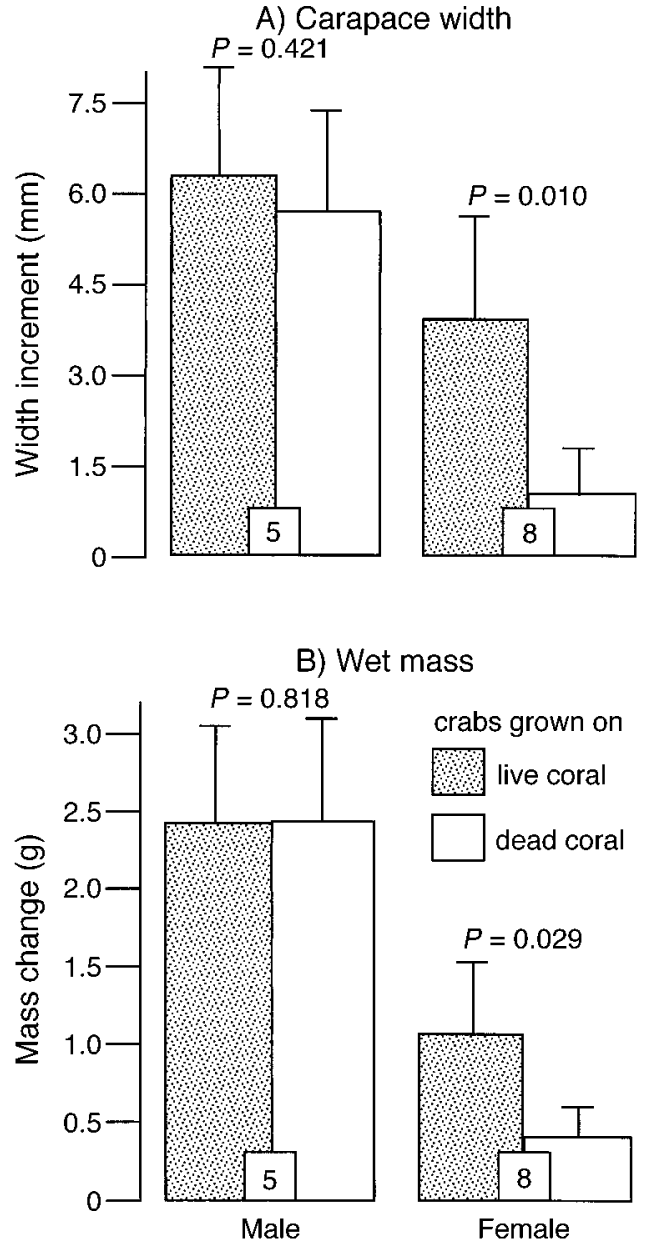

FIG. 10. Growth (mean +1 SE) of Mithrax forceps on live and dead Oculina arbuscula. Statistical contrasts of growth were made separately for male and female crabs using paired $t$ tests on change in (A) carapace width and (B) wet mass. $N$ is given at the base of each pair of bars.

plex organisms in the marine environment (e.g., Vance 1978, Witman 1987, Littler et al. 1995), so this type of mutualism may be more important than is currently appreciated. These structurally complex organisms provide protective habitat for a diverse suite of organisms. Individual Oculina heads have been reported to support as many as 161 species, and a total of 309 species from taxa as diverse as cnidarians, mollusks, crustaceans, tunicates, and fishes have been recorded living on, or in, the coral (McCloskey 1970). Most of these species are not found in the surrounding reef habitat, suggesting that without the corals they could become locally extinct (McCloskey 1970). By increasing host growth rates and/or survivorship, mutualists such as Mithrax facilitate the production and maintenance of biogenic structure and may therefore function as keystone species within this assemblage of hostassociated organisms.

Because the effects of Mithrax on the benthic sea- weed community are highly localized around the host coral, Mithrax creates small patches of intense, nonselective, grazing superimposed on the background of selective grazing by more mobile herbivores like fishes and urchins. On a landscape level, the combined effect of both types of grazing should result in a mosaic of patches with high and low algal density. Such increases in patchiness and local habitat diversity can have important consequences for species diversity at both the local and regional scale (Abele 1974, Heck and Wetstone 1977, Hay 1985, 1986, Stoner and Lewis 1985, Harrison 1997). Additionally, local reductions in plant density may alter the nature of inter- and intraspecific interactions among seaweeds (Schiel 1985, Paine 1990, Steneck et al. 1991), reduce the density of seaweedassociated invertebrates (Stoner and Lewis 1985, Dean and Connell 1987), and decrease the abundance and recruitment of reef fishes (Anderson 1994, Carr 1994, Levin and Hay 1996). Thus, although the impact of small, nonselective grazers may be spatially restricted, this type of grazing clearly merits consideration in models of herbivore impact on community dynamics and local ecosystem function.

\section{Spatial and temporal variability in mutualisms}

Conceptual models have suggested that certain types of positive interactions will be most common where physical conditions are harsh or consumer pressure is high (Bertness and Callaway 1994). This dependence on physical or biotic conditions outside the association, which are likely to vary over time and space, makes these interactions particularly subject to variability in outcome (see e.g., Holmgren et al. 1997). Similarly, Addicott (1984) was among the first to draw attention to the idea that mutualisms may be particularly important in areas of biotic or abiotic stress. As such, mutualisms may exhibit even greater context dependency than other positive interactions because multiple stresses must be present for the interaction to be re-

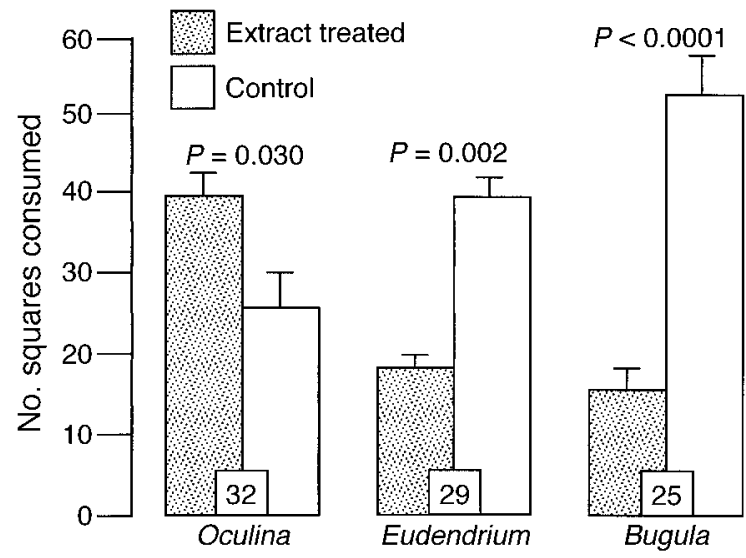

FIG. 11. Effects of invertebrate chemical extracts on feeding by Mithrax forceps. Statistical analyses were by paired $t$ test. $N$ is given at the base of each pair of bars. 
ciprocally positive. For example, in the encroachment experiment, community cover was low on the deep blocks (Fig. 3) and dominated by species chemically defended from Mithrax (Figs. 4 and 11). As a result, Mithrax had no significant impact on community cover or coral growth at this depth. However, because many of the invertebrates that co-occur with Oculina in turbid waters also grow slowly or are susceptible to consumption by large, mobile predators like fishes or urchins (Sutherland 1974, Karlson 1978), symbiotic mediation of competition may be less critical for coral growth and survival in poorly lit waters. Under these conditions, the interaction is best regarded as commensal because the crab does not affect the coral, but continues to use it for protection from predators and presumably continues to acquire food from the coral (although this has not been tested under low-light conditions that may restrict the coral's ability to produce energetic rewards for the crab).

Despite the lack of a crab effect on coral growth and community cover during the summer at the invertebrate-dominated deep site, Mithrax mediated coral competition with invertebrates under some circumstances (Fig. 2). The abundance of the tunicates and anemones that overgrew Oculina without crabs in the fouling experiment is controlled, to some extent, by fishes and urchins in the summer (Karlson 1978), but these predators migrate offshore or become inactive during the winter months (Karlson 1978, Hay and Sutherland 1988) when much of this experiment was conducted. Because fouling by these invertebrates can pose a threat to corals in the winter, crabs become seasonally important mediators of competition between corals and other invertebrates. Such seasonal changes in the nature and outcome of mutualisms are likely to be common wherever the stress in question (i.e., drought, competition, predation pressure) also varies throughout the year. For example, the net outcome of the interaction between desert annuals and perennial shrubs changes predictably with water availability throughout the year (Holzapfel and Mahall 1999).

If we had only examined this interaction in poorly lit sites (where corals are most common), we would have concluded that Mithrax has little effect on its host because Mithrax only benefits Oculina under conditions of intense competition such as occur in well-lit areas where seaweeds are common (Fig. 5). Such biological or physical stresses are likely to be greatest near the environmental limits of an organism, thus mutualisms that ameliorate these stresses may be most common near the distributional limits of organisms. Positive intraspecific interactions may thus be prevalent where intraspecific competition is relatively weak such as soft sediment communities or at the upper border of species distributions in the rocky intertidal (e.g., Bertness and Grosholz 1985, Peterson and Black 1993, Bertness and Leonard 1997). Additionally, we suggest that the forging of alliances with natural enemies of interspecific competitors may be common where this kind of competition is particularly intense. Continued focus on patterns of spatial and temporal variation in the outcomes of these interactions should yield a clearer picture of the conditions under which mutualisms are (and are not) likely to play important roles in structuring ecological communities.

\section{ACKNOWLEDGMENTS}

This investigation was funded by the National Science Foundation through grant OCE no. 95-29784 to M. Hay and a predoctoral fellowship to J. Stachowicz, and through a University of North Carolina Graduate School Dissertation Fellowship to J. Stachowicz. Assistance underwater and in the lab throughout this study was cheerfully provided by S. Bullard, G. Cetrulo, E. Cruz-Rivera, M. Deal, Z. Feldman, C. Kicklighter, N. Lindquist, G. Safrit, and E. Sotka. Comments by M. Bertness, B. Menge, R. Peet, C. Peterson, and an anonymous reviewer improved previous drafts of the manuscript. We are indebted to M. Miller for providing algal cover data from North Carolina offshore reefs and H. Paerl for use of the light meter.

\section{Literature Cited}

Abele, L. G. 1974. Species diversity of decapod crustaceans in marine habitats. Ecology 55:156-161.

Addicott, J. H. 1984. Mutualistic interactions in population and community processes. Pages 437-455 in P. W. Price, C. N. Slobodchikoff, and W. S. Gaud, editors. A new ecology: novel approaches to interactive systems. Wiley Interscience, New York, New York, USA.

Alldredge, J. R., and J. T. Ratti. 1986. Comparison of some statistical techniques for analysis of resource selection. Journal of Wildlife Management 50:157-165.

Alldredge, J. R., and J. T. Ratti. 1992. Further comparison of some statistical techniques for analysis of resource selection. Journal of Wildlife Management 56:1-9.

Anderson, T. W. 1994. Role of macroalgal structure in the distribution and abundance of a temperate reef fish. Marine Ecology Progress Series 113:279-290.

Atsatt, P. R., and D. J. O'Dowd. 1976. Plant defense guilds. Science 193:24-29.

Beattie, A. J. 1985. Evolutionary ecology of ant-plant mutualisms. Cambridge University Press, Cambridge, UK

Benson, A., and L. Muscatine. 1974. Wax in coral mucus: energy transfer from corals to reef fishes. Limnology and Oceanography 19:810-814.

Bertness, M. D., and R. M. Callaway. 1994. Positive interactions in communities: a post cold war perspective. Trends in Ecology and Evolution 9:191-193.

Bertness, M. D., and E. Grosholz. 1985. Population dynamics of the ribbed mussel, Geukensia demissa; the costs and benefits of an aggregated distribution. Oecologia 67:192204.

Bertness, M. D., and S. D. Hacker. 1994. Physical stress and positive associations among marsh plants. American Naturalist 142:718-724.

Bertness, M. D., and G. H. Leonard. 1997. The role of positive interactions in communities: lessons from intertidal environments. Ecology 78:1976-1989.

Bolser, R. C., and M. E. Hay. 1996. Are tropical plants better defended? Palatability and defenses of temperate vs. tropical seaweeds. Ecology 77:2269-2286.

Boucher, D. H. 1985. The biology of mutualism. Croom Helm, London, UK.

Boucher, D. H., S. James, and K. H. Keeler. 1982. The ecology of mutualism. Annual Review of Ecology and Systematics 13:315-347. 
Bronstein, J. L. 1994. Our current understanding of mutualism. Quarterly Review of Biology 69:31-51.

Buss, L. W. 1985. The uniqueness of the individual revisited. Pages 467-505 in J. B. C. Jackson, L. W. Buss, and R. E. Cook, editors. Population biology and evolution of clonal organisms. Yale University Press, New Haven, Connecticut, USA.

Callaway, R. M., and L. R. Walker. 1997. Competition and facilitation: a synthetic approach to interactions in plant communities. Ecology 78:1958-1965.

Carr, M. H. 1994. Effects of macroalgal dynamics on recruitment of a temperate reef fish. Ecology 75:1320-1333.

Castro, P. 1976. Brachyuran crabs symbiotic with scleractinian corals: a review of their biology. Micronesica 12 99-110.

Cerame-Vivas, M. J., and I. E. Gray. 1966. The distribution pattern of benthic invertebrates of the continental shelf off North Carolina. Ecology 47:260-270.

Choat, J. H. 1991. The biology of herbivorous fishes on coral reefs. Pages 120-155 in P. F. Sale, editor. The ecology of fishes on coral reefs. Academic, San Diego, California, USA.

Coen, L. D. 1988. Herbivory by crabs and the control of algal epibionts on Caribbean host corals. Oecologia 75: 198-203.

Coles, S. L., and R. Strathmann. 1973. Observations on coral mucus "flocs" and their potential trophic significance. Limnology and Oceanography 18:673-678.

Coyer, J. A., R. F. Ambrose, J. M. Engle, and J. C. Carroll 1993. Interactions between corals and algae on a temperate zone rocky reef: mediation by sea urchins. Journal of Experimental Marine Biology and Ecology 101:161-174.

Cronin, G., and M. E. Hay. 1996. Susceptibility to herbivores depends on the recent history of both the plant and the animal. Ecology 77:1531-1543.

Crossland, C. J., D. J. Barnes, and M. A. Borowitzka. 1980. Diurnal lipid and mucus production in the staghorn coral Acropora acuminata. Marine Biology 60:81-90.

Davies, P. S. 1991. Effects of daylight variations on the energy budgets of shallow water corals. Marine Biology 108:137-144.

Day, R. W., and G. P. Quinn. 1989. Comparisons of treatments after an analysis of variance in ecology. Ecological Monographs 59:433-463.

Dean, R. L., and J. H. Connell. 1987. Marine invertebrates in algal succession. II. Tests of hypotheses to explain changes in diversity with succession. Journal of Experimental Marine Biology and Ecology 109:217-247.

de Nys, R., J. C. Coll, and I. R. Price. 1991. Chemically mediated interactions between the red alga Plocamium hamatum (Rhodophyta) and the octocoral Sinularia cruciata (Alcyonacea). Marine Biology 108:315-320.

Ducklow, H. W., and R. Mitchell. 1979. Composition of mucus released by coral reef coelenterates. Limnology and Oceanography 24:706-714.

Ebeling, A. W., and M. A. Hixon. 1991. Tropical and temperate reef fishes: a comparison of community structures Pages 509-563 in P. F. Sale, editor. The ecology of fishes on coral reefs. Academic, San Diego, California, USA.

Gaines, S. D., and J. Lubchenco. 1982. A unified approach to plant-herbivore interactions. II. Biogeography. Annual Review of Ecology and Systematics 13:111-138.

Glynn, P. W. 1983. Increased survivorship in corals harboring crustacean symbionts. Marine Biology Letters 4:105111.

1987. Some ecological consequences of coral-crustacean guard mutualisms in the Indian and Pacific Oceans. Symbiosis 4:301-324.

Hacker, S. D., and S. D. Gaines. 1997. Some implications of direct positive interactions for community species diversity. Ecology 78:1990-2003.

Harrison, S. 1997. How natural habitat patchiness affects the distribution of diversity in Californian serpentine chaparral. Ecology 78:1898-1906.

Hatcher, B. G., and D. W. Rimmer. 1985. The role of grazing in controlling benthic community structure on a high latitude coral reef: measurements of grazing intensity. Proceedings of the Fifth International Coral Reef Congress 6 : 229-236.

Hay, M. E. 1985. Spatial patterns of herbivore impact and their importance in maintaining algal species richness. Proceedings of the Fifth International Coral Reef Congress 4: 29-34.

1986. Associational plant defenses and the maintenance of species diversity: turning competitors into accomplices. American Naturalist 128:617-641.

1992. The role of seaweed chemical defenses in the evolution of feeding specialization and in the mediation of complex interactions. Pages 93-118 in V. J. Paul, editor. Ecological roles of marine natural products. Comstock, Ithaca, New York, USA.

1997. The ecology and evolution of seaweed-herbivore interactions on coral reefs. Coral Reefs 16:S67-S76.

Hay, M. E., J. E. Duffy, C. A. Pfister, and W. Fenical. 1987. Chemical defense against different marine herbivores: are amphipods insect equivalents? Ecology 68:1567-1580.

Hay, M. E., Q. E. Kappel, and W. Fenical. 1994. Synergisms in plant defenses against herbivores: interactions of chemistry, calcification, and plant quality. Ecology 75:17141726.

Hay, M. E., P. E. Renaud, and W. Fenical. 1988. Large mobile versus small sedentary herbivores and their resistance to seaweed chemical defenses. Oecologia 75:246-252.

Hay, M. E., J. J. Stachowicz, E. Cruz-Rivera, S. Bullard, M. S. Deal, and N. Lindquist. 1998. Bioassays with marine and freshwater macro-organisms. Pages $39-142$ in J. G. Millar and K. F. Haynes, editors. Methods in chemical ecology. Chapman and Hall, New York, New York, USA.

Hay, M. E., and J. P. Sutherland. 1988. The ecology of rubble structures of the South Atlantic Bight: a community profile. U.S. Fish and Wildlife Service Biological Report 85(7.20), Washington, D. C., USA.

Heck, K. L., and G. S. Wetstone. 1977. Habitat complexity and invertebrate species richness and abundance in tropical seagrass meadows. Journal of Biogeography 4:135-142.

Holmgren, M., M. Scheffer, and M. A. Huston. 1997. The interplay of facilitation and competition in plant communities. Ecology 78:1966-1975.

Holzapfel, C., and B. E. Mahall. 1999. Bidirectional facilitation and interference between shrubs and annuals in the Mojave desert. Ecology 80, in press.

Horn, M. H. 1989. Biology of marine herbivorous fishes. Oceanography and Marine Biology Annual Review 27: $167-272$.

Hughes, T. P. 1989. Community structure and diversity of coral reefs: the role of history. Ecology 70:275-279.

. 1994. Catastrophes, phase shifts, and large-scale degradation of a Caribbean coral reef. Science 265:15471550.

Jacques, T. G., N. Marshall, and M. E. Q. Pilson. 1983. Experimental ecology of the temperate scleractinian coral Astrangia danae. II. Effects of temperature, light intensity and symbiosis with zooxanthellae on metabolic rate and calcification. Marine Biology 76:135-148.

Janzen, D. H. 1966. Coevolution of mutualism between ants and acacias in Central America. Evolution 20:249-275.

. 1969. Allelopathy by myrmecophytes: the ant Azteca as an allelopathic agent of Cecropia. Ecology 50:147-153. Johannes, R. E., W. J. Weibe, C. J. Crossland, D. W. Rimmer, 
and S. V. Smith. 1983. Latitudinal limits to coral reef growth. Marine Ecology Progress Series 11:105-111.

Jones, C. G., J. H. Lawton, and M. Shachak. 1997. Positive and negative effects of organisms as physical ecosystem engineers. Ecology 78:1946-1957.

Jormalainen, V., and J. Tuomi. 1989. Sexual differences in habitat selection and activity of the colour polymorphic isopod Idotea baltica. Animal Behavior 38:576-585.

Karlson, R. H. 1978. Predation and space utilization patterns in a marine epifaunal community. Journal of Experimental Marine Biology and Ecology 31:225-239.

Knudsen, J. W. 1967. Trapezia and Tetralia (Decapoda, Brachyura, Xanthidae) as obligate ectoparasites of pocilloporid and acroporid corals. Pacific Science 21:51-57.

Lawton, J. H., and C. G. Jones. 1995. Linking species and ecosystems: organisms as ecosystem engineers. Pages 141150 in C. G. Jones and J. H. Lawton, editors. Linking species and ecosystems. Chapman and Hall, New York, New York, USA.

Levin, P. S., and M. E. Hay. 1996. Responses of temperate reef fishes to alterations in algal structure and species composition. Marine Ecology Progress Series 134:37-47.

Lewis, S. M. 1986. The role of herbivorous fishes in the organization of a Caribbean reef community. Ecological Monographs 56:183-200.

Link, G. W. 1980. Age, growth, reproduction, feeding, and ecological observations on the three species of Centropristis (Pices: Serranidae) in North Carolina waters. Dissertation. University of North Carolina, Chapel Hill, North Carolina, USA.

Littler, M. M., D. S. Littler, and P. R. Taylor. 1995. Selective herbivore increases biomass of its prey: a chiton-coralline reef-building association. Ecology 76:1666-1681.

Littler, M. M., P. R. Taylor, and D. S. Littler. 1986. Plant defense associations in the marine environment. Coral Reefs 5:63-71.

Lubchenco, J., and S. D. Gaines 1981. A unified approach to marine plant-herbivore interactions. I. Populations and communities. Annual Review of Ecology and Systematics 12:405-437

Macintyre, I. G., and O. H. Pilkey. 1969. Tropical reef corals: tolerance of low temperatures on the North Carolina continental shelf. Science 166:374-375.

McCloskey, L. R. 1970. The dynamics of the community associated with a marine scleractinian coral. Internationale Revue der Gesamten Hydrobiologie 55:13-81.

Merilaita, S., and V. Jormalainen. 1997. Evolution of sex differences in microhabitat choice and colour polymorphism in Idotea baltica. Animal Behavior 54:769-778.

Miller, M. W. 1995. Growth of a temperate coral: effects of temperature, light, depth and heterotrophy. Marine Ecology Progress Series 122:217-225.

. 1998. Coral/seaweed competition and the control of reef community structure within and between latitudes Oceanography and Marine Biology: An Annual Review 36 : 65-96.

Miller, M. W., and M. E. Hay. 1996. Coral-seaweed-grazernutrient interactions on temperate reefs. Ecological Monographs 66:323-344.

Muscatine, L., and J. W. Porter. 1977. Reef corals: mutualistic symbioses adapted to nutrient poor environments. BioScience 27:454-460.

Paine, R. T. 1990. Benthic macroalgal competition: complications and consequences. Journal of Phycology 26:12-17.

Peckol, P. 1982. Seasonal occurrence and reproduction of some marine algae of the continental shelf, North Carolina. Botanica Marina 25:185-190.

Peckol, P., and R. B. Searles. 1984. Temporal and spatial patterns of growth and survival of invertebrate and algal populations of a North Carolina continental shelf community. Estuarine, Coastal and Shelf Science 18:133-143.

Peterson, C. H., and R. Black. 1993. Experimental tests of the advantages and disadvantages of high density for two coexisting cockles in a Southern Ocean lagoon. Journal of Animal Ecology 62:614-633.

Peterson, C. H., and R. Black. 1994. An experimentalist's challenge: when artifacts of intervention interact with treatments. Marine Ecology Progress Series 111:289-297.

Peterson, C. H., and P. E. Renaud. 1989. Analysis of feeding preference experiments. Oecologia 80:82-86.

Pfister, C. A., and M. E. Hay. 1988. Associational plant refuges: convergent patterns in marine and terrestrial communities result from different mechanisms. Oecologia 77: 118-129.

Regal, P. J. 1977. Ecology and the evolution of flowering plant dominance. Science 196:622-629.

Richardson, J. P. 1978. Effects of environmental factors on the life histories and seasonality of some inshore benthic marine algae in North Carolina. Dissertation. University of North Carolina, Chapel Hill, North Carolina, USA.

Roa, R. 1992. Design and analysis of multiple-choice feeding-preference experiments. Oecologia 89:509-515.

Ruppert, E., and R. Fox. 1988. Seashore animals of the southeast. University of South Carolina Press, Columbia, South Carolina, USA.

Schiel, D. R. 1985. Growth, survival and reproduction of two species of marine algae at different densities in natural stands. Journal of Ecology 73:199-217.

Schumaker, H., and H. Zibrowius. 1985. What is hermatypic? A redefinition of ecological groups of corals and other organisms. Coral Reefs 4:1-9.

Squires, D. F., and I. W. Keyes. 1967. Marine fauna of New Zealand: scleractinian corals. Bulletin of the New Zealand Department of Scientific and Industrial Research 185:946.

Stachowicz, J. J., and M. E. Hay. 1996. Facultative mutualism between an herbivorous crab and a coralline alga: advantages of eating noxious seaweeds. Oecologia 105: 377-387.

Steneck, R. S. 1982. A limpet-coralline alga association: adaptations and defenses between a selective herbivore and its prey. Ecology 63:507-522.

Steneck, R. S., S. D. Hacker, and M. N. Dethier. 1991. Mechanisms of competitive dominance among crustose coralline algae: an herbivore-mediated competitive reversal. Ecology 72:938-950.

Stimson, J. 1990. Stimulation of fat-body production in the polyps of the coral Pocillopora damicornis by the presence of mutualistic crabs in the genus Trapezia. Marine Biology 106:211-218.

Stoner, A. W., and F. G. Lewis III. 1985. The influence of quantitative and qualitative aspects of habitat complexity in tropical sea-grass meadows. Journal of Experimental Marine Biology and Ecology 94:19-40.

Sutherland, J. P. 1974. Multiple stable points in natural communities. American Naturalist 108:859-873.

Vance, R. R. 1978. A mutualistic interaction between a sessile marine clam and its epibionts. Ecology 59:679-685.

Williams, A. B. 1984. Shrimps, lobsters and crabs of the Atlantic coast. Smithsonian, Washington, D.C., USA.

Witman, J. D. 1987. Subtidal coexistence: storms, grazing, mutualism and the zonation of kelps and mussels. Ecological Monographs 57:167-187. 